\title{
Changes in the regulation of the Notch signaling pathway are temporally correlated with regenerative failure in the mouse cochlea
}

\author{
Juan C. Maass ${ }^{1,2,3,4}$, Rende Gu ${ }^{1}$, Martin L. Basch ${ }^{1}$, Joerg Waldhaus ${ }^{5}$, Eduardo Martin \\ Lopez $^{1}$, Anping Xia ${ }^{5}$, John S. Oghalai ${ }^{5}$, Stefan Heller ${ }^{5}$ and Andrew K. Groves ${ }^{1,6,7 *}$ \\ ${ }^{1}$ Department of Neuroscience, Baylor College of Medicine, Houston, TX, USA, ${ }^{2}$ Department of Otolaryngology, Hospital \\ Clínico Universidad de Chile, Santiago, Chile, ${ }^{3}$ Interdisciplinary Program of Physiology and Biophysics, ICBM Universidad de \\ Chile, Santiago, Chile, ${ }^{4}$ Department of Otolaryngology, Clínica Alemana de Santiago, Facultad de Medicina Clínica \\ Alemana-Universidad del Desarrollo, Santiago, Chile, ${ }^{5}$ Department of Otolaryngology - Head and Neck Surgery, Stanford \\ University School of Medicine, Palo Alto, CA, USA, ${ }^{6}$ Department of Molecular and Human Genetics, Baylor College of \\ Medicine, Houston, TX, USA, ${ }^{7}$ Program in Developmental Biology, Baylor College of Medicine, Houston, TX, USA
}

\section{OPEN ACCESS}

Edited by:

Qi Yuan,

Memorial University, Canada

Reviewed by:

Fernando Giraldez,

Universitat Pompeu Fabra, Spain

Nicolas Daudet,

University College London, UK

Jian Zuo,

St. Jude Children's Research

Hospital, USA

*Correspondence:

Andrew K. Groves, Department of Molecular and Human Genetics,

Baylor College of Medicine, BCM295, 1 Baylor Plaza, Houston, TX 77030, USA

akgroves@bcm.edu

Received: 16 December 2014 Accepted: 10 March 2015 Published: 31 March 2015

Citation:

Maass JC, Gu R, Basch ML, Waldhaus J, Lopez EM, Xia A, Oghalai JS, Heller $S$ and Groves AK (2015) Changes in the regulation of the Notch signaling pathway are temporally correlated with regenerative failure in the mouse cochlea.

Front. Cell. Neurosci. 9:110. doi: 10.3389/fncel.2015.00110
Sensorineural hearing loss is most commonly caused by the death of hair cells in the organ of Corti, and once lost, mammalian hair cells do not regenerate. In contrast, other vertebrates such as birds can regenerate hair cells by stimulating division and differentiation of neighboring supporting cells. We currently know little of the genetic networks which become active in supporting cells when hair cells die and that are activated in experimental models of hair cell regeneration. Several studies have shown that neonatal mammalian cochlear supporting cells are able to trans-differentiate into hair cells when cultured in conditions in which the Notch signaling pathway is blocked. We now show that the ability of cochlear supporting cells to trans-differentiate declines precipitously after birth, such that supporting cells from six-day-old mouse cochlea are entirely unresponsive to a blockade of the Notch pathway. We show that this trend is seen regardless of whether the Notch pathway is blocked with gamma secretase inhibitors, or by antibodies against the Notch1 receptor, suggesting that the action of gamma secretase inhibitors on neonatal supporting cells is likely to be by inhibiting Notch receptor cleavage. The loss of responsiveness to inhibition of the Notch pathway in the first postnatal week is due in part to a down-regulation of Notch receptors and ligands, and we show that this down-regulation persists in the adult animal, even under conditions of noise damage. Our data suggest that the Notch pathway is used to establish the repeating pattern of hair cells and supporting cells in the organ of Corti, but is not required to maintain this cellular mosaic once the production of hair cells and supporting cells is completed. Our results have implications for the proposed used of Notch pathway inhibitors in hearing restoration therapies.

Keywords: notch, hair cell, supporting cell, cochlea, regeneration 


\section{Introduction}

The Notch signaling pathway is an evolutionarily ancient form of cell-cell communication. During Notch signaling, the binding of membrane-bound ligands of the Delta and Jagged/Serrate families to Notch receptors causes the cleavage of the receptor and release of an intracellular domain which travels to the nucleus and participates in transcriptional activation (ArtavanisTsakonas et al., 1999; Ilagan and Kopan, 2007; ArtavanisTsakonas and Muskavitch, 2010; Hori et al., 2013). Notch signaling is deployed in the development of many tissues, and can influence cell fate through lateral inhibition with feedback (Chitnis, 1995; Formosa-Jordan et al., 2013), inductive signaling (frequently to establish boundaries of different cell types) or by the asymmetrical inheritance of fate determinants that affect Notch signaling (Bray, 2006).

Notch signaling regulates many aspects of inner ear development (Kelley, 2003, 2006, 2007; Murata et al., 2012). During the induction of the otic placode, the anlagen of the inner ear, Jagged1 activation of Notch signaling acts to strengthen otic placode fate in response to FGF and Wnt signals (Jayasena et al., 2008; Groves and Fekete, 2012). As the first neuroblasts begin to differentiate and delaminate from the otocyst, Notch-Delta signaling regulates the proportion of progenitor cells that differentiate as neurons by lateral inhibition (Adam et al., 1998; Abelló et al., 2007; Daudet et al., 2007; Kiernan, 2013; Neves et al., 2013a). As the first sensory regions of the inner ear begin to develop, Notch-Jagged1 signaling helps maintain and promote the fate of vestibular sensory regions of the ear through lateral induction (Eddison et al., 2000; Daudet and Lewis, 2005; Kiernan et al., 2005a; Brooker et al., 2006; Daudet et al., 2007; Hartman et al., 2010; Pan et al., 2010, 2013; Neves et al., 2011, 2013a,b), although it is less clear if this mode of sensory induction also occurs in the cochlea (Basch et al., 2011; Yamamoto et al., 2011). Finally, as hair cell and supporting cells begin to differentiate from sensory progenitor cells in prosensory patches, hair cells begin to express the Notch ligands Delta1 and Jagged2 (Dll1, Jag2) on their cell surface, and signaling by these ligands through the Notch1 receptor on nascent supporting cells induces and maintains supporting cell fate though lateral inhibition. Accordingly, pharmacological or genetic disruption of Notch1, Dll1 or Jag2, singly or in combination, leads to a failure of Notch signaling and an increase in the number of hair cells at the expense of supporting cells, likely through loss of lateral inhibition (Kiernan et al., 2005a; Brooker et al., 2006). Mutation or knock-down of downstream transcriptional effectors of Notch signaling, such as members of the Hes and Hey gene families, also leads to an increase in hair cell numbers at the expense of supporting cells (Zheng et al., 2000; Zine et al., 2001; Hayashi et al., 2008; Li et al., 2008; Doetzlhofer et al., 2009; Tateya et al., 2011; Benito-Gonzalez and Doetzlhofer, 2014).

A number of studies suggest that Notch signaling between hair cells and supporting cells continues in the sensory end organs of the mammalian inner ear after birth (Zine et al., 2000; Murata et al., 2006; Yamamoto et al., 2006;
Hartman et al., 2007, 2009; Hori et al., 2007; Batts et al., 2009; Doetzlhofer et al., 2009; Lin et al., 2011; Liu et al., 2012a,b). Downstream effectors of Notch signaling can be detected in the cristae and maculae of the vestibular system (Hartman et al., 2009; Wang et al., 2010; Lin et al., 2011; Slowik and Bermingham-McDonogh, 2013), and blockade of Notch signaling in the adult vestibular system can induce the formation of ectopic hair cells at the expense of supporting cells (Lin et al., 2011; Slowik and Bermingham-McDonogh, 2013). Similarly, inhibition of Notch signaling in the neonatal organ of Corti also down-regulates some downstream effectors of Notch signaling in supporting cells and leads to the rapid formation of extra hair cells (Doetzlhofer et al., 2009; Korrapati et al., 2013; Mizutari et al., 2013; Bramhall et al., 2014). In both the neonatal cochlea and adult vestibular system, the generation of hair cells has been proposed to occur through a direct trans-differentiation of supporting cells without cell division (Doetzlhofer et al., 2009; Lin et al., 2011; Bramhall et al., 2014), a mode of differentiation that has also been observed during hair cell regeneration in birds (Stone and Cotanche, 2007).

Recently, application of gamma secretase inhibitors that attenuate the Notch pathway to the noise-damaged cochlea has been shown to generate small numbers of new hair cells and a partial restoration of hearing (Mizutari et al., 2013), suggesting that the Notch pathway may still be active in the mature cochlea. However, two issues remain unaddressed by this study. First, it is not clear to what extent components of the Notch signaling pathway-Notch receptors, Notch ligands and their downstream effectors-are expressed in the maturing cochlea (Batts et al., 2009). Indeed, two studies examining the presence of the active cleaved intracellular portion of the Notch1 receptor found very little evidence for Notch activation in the cochlea 1 week after birth (Murata et al., 2006; Liu et al., 2013). Moreover, although gamma secretase inhibitors are known to inhibit cleavage and activation of Notch receptors, they also cleave many other membrane proteins, and so it is possible that their effects in the cochlea may not be specific to the Notch pathway (Kopan and Ilagan, 2004).

In the present study, we compared the effects of gamma secretase inhibitors or blocking antibodies to the Notch1 receptor on the patterning of hair cells and supporting cells in organ cultures of the neonatal cochlea. In each case, we found that inhibitor treatment causes an increase in hair cell numbers at the expense of supporting cells, suggesting that both inhibitors are likely causing supporting cell trans-differentiation through inhibition of the Notch pathway. However, we find a precipitous age-dependent decline in the ability of these inhibitors to cause supporting cell trans-differentiation into hair cells. This decline in response to Notch inhibition progresses in a basal-apical gradient along the organ of Corti, consistent with the gradient of cellular maturation in the cochlea, and by 6 days after birth, the organ of Corti is essentially unresponsive to Notch inhibition in culture. We combined in situ hybridization, Q-PCR quantitation and single cell Fluidigm analysis of Notch pathway components and showed that Notch receptors, 
ligands and effectors are down-regulated from the organ of Corti in basal-apical gradient during the first postnatal week, and are at least an order of magnitude lower in mature animals, even after noise damage. Our results suggest that the Notch signaling pathway is deployed to establish the pattern of hair cells and supporting cells in the cochlea, but is not required to maintain this pattern in the mature organ of Corti.

\section{Materials and Methods}

\section{Mice}

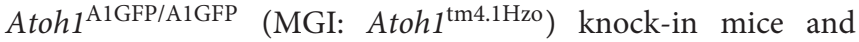
Atoh $1^{\mathrm{GFP}}$ transgenic reporter mice were generated as previously described (Lumpkin et al., 2003; Rose et al., 2009). ICR mice were used for Notch Intracellular Domain (NICD) immunostaining. Noise damage experiments were performed on wild type CBA/CaJ mice. Pillar cells and Deiters' cells were purified from Fgfr3-iCreER ${ }^{\mathrm{T} 2}$ (Young et al., 2010) mice mated with Ai14:Rosa ${ }^{\text {tdTom }}$ reporter mice (Jackson, \#007908). All animal experiments were approved by the Baylor College of Medicine or Stanford University Institutional Animal Care and Use committees.

\section{Cochlear Organ Culture}

Cochleas were dissected in ice cold HBSS immediately after euthanasia. Briefly, the heads were bisected, the temporal bone was removed from the skull base and the otic capsule was removed with forceps until the intact membranous cochlea was separated from the bony structures. For P0 and P3 animals, the cochlear duct was peeled out from the modiolus and the medial structures (Kölliker and Corti's organs) were separated from the lateral wall, Reissner's membrane and the stria vascularis. For P6 mice, in order to preserve the structures in the organ of Corti, the cochlear duct was gently separated from the modiolus by cutting between them with forceps and the lateral wall, stria vascularis and Reissner's membrane were partially removed after cutting with 27 gauge needle. Immediately after dissection, the explants were placed on top of filter membranes with $1 \mu \mathrm{m}$ pores (SPI-pore or Whatman) floating in DMEM/F12 (Hepes) supplemented with B27 supplements (Life Technologies), 1 $\mathrm{mM}$ $\mathrm{N}$-acetylcysteine (Sigma), $5 \mathrm{ng} / \mathrm{ml} \mathrm{EGF}$ and $2.5 \mathrm{ng} / \mathrm{ml} \mathrm{FGF2}$ and $67 \mu \mathrm{g} / \mathrm{ml}$ penicillin. In some cultures DMEM/F12 medium was supplemented with N2 supplements (Life Technologies), Nacetylcysteine and penicillin. For Notch inhibition experiments, cultures were supplemented with $0.75-10 \mu \mathrm{M}$ DAPT (Gamma secretase inhibitor IX, Calbiochem EMD) or DMSO $0.04 \%$ v/v (Life Technologies). Anti Notch1-specific antibodies and control IgD antibodies ( $\mathrm{Wu}$ et al., 2010) were provided by Genentech and used at $2 \mu \mathrm{g} / \mathrm{ml}$. The cultures were maintained for $1 \mathrm{~h}, 1,2$ or 3 days in vitro (DIV) at $37^{\circ} \mathrm{C}$ in $5 \% \mathrm{CO}_{2}$.

\section{Immunostaining, Microscopy and Quantification}

Whole cochlear explants were fixed in $4 \%$ paraformaldehyde, then permeabilized and blocked in $0.2 \%$ Triton X-100 and
$10 \%$ donkey serum in PBS. The explants were incubated with primary antibodies overnight at $4^{\circ} \mathrm{C}$, washed in PBST ( $0.1 \%$ Triton $\mathrm{X}-100$ in $\mathrm{PBS})$ and incubated with secondary antibodies for $2 \mathrm{~h}$ at room temperature, followed by 3 further washes in PBST and then incubated in $10 \mu \mathrm{g} / \mathrm{ml}$ DAPI for $10 \mathrm{~min}$. Primary antibodies used were rabbit polyclonal anti-Myosin VIIa (1:500; Proteus Biosciences) and mouse monoclonal anti-GFP (1:200; Invitrogen). Secondary antibodies were Alexa Fluor 594 and 488 (Invitrogen). Images were obtained on an Axio Observer Zeiss microscope with an Apotome2 structured illumination attachment and analyzed in Axiovision 4.8 (Zeiss) and Image J (NIH) using Bioformat and the Cell Counter plugins. The cochlea was divided in five pieces: the tip, the apex, the middle, the base and the hook, and the center of each portion was analyzed, discarding the tip and the hook. Cell counts across different areas of the cochlea were normalized to cells per $100 \mu \mathrm{m}$ and were expressed as a percentage increase with respect to control conditions. Significant differences were analyzed using a Mann-Whitney test for pairwise comparisons.

For NICD immunostaining in sections the protocol was modified from Morimoto et al. (2010). Briefly the heads of P0, P3 and P6 ICR mice were mounted in paraffin blocks and sectioned at $10 \mu \mathrm{m}$. The sections were rehydrated, bleached in $\mathrm{H}_{2} \mathrm{O}_{2}$ and boiled in a pressure cooker in antigen unmasking solution (Vectorlabs) for $20 \mathrm{~min}$. The sections were then permeabilized, blocked and incubated with a cleaved Notch1 antibody (val1744; 1:100; Cell signaling) and anti- Myosin VIIa (1:500; Proteus Biosciences). The signal was amplified with Vectastain ABC Kit (rabbit IgG) (Vectorlabs) as indicated by manufacturer. The color was developed for 5-10 min with TSA Tyramide Cy3 Reagent (diluted 1:100 after reconstitution; Perkin Elmer) and then stained with DAPI. Images were obtained on a Zeiss Axio Observer microscope with an Apotome2 structured illumination attachment.

\section{In Situ Hybridization}

Digoxygenin-labeled in situ probe synthesis was performed on linearized plasmid DNA using standard protocols (Stern, 1998). The following mouse cDNA probes were used in the study and kindly provided by the investigators listed: Notch1, Jag1, Dll1 (Gerry Weinmaster), Notch3 (Urban Lendahl), Hes5 (Ryoichiro Kageyama), Hey1, Hey2, HeyL (Manfred Gessler), and Atoh1 (Huda Zoghbi). A cDNA clone for Jag2 (BC010982) was purchased from open Biosystems. The in situ hybridization procedure for frozen sections was modified from previous protocols (Harland, 1991; Birren et al., 1993; Groves et al., 1995). Heads of perinatal mouse pups were fixed in $4 \%$ paraformaldehyde in PBS overnight at $4^{\circ} \mathrm{C}$, cryoprotected in $30 \%$ sucrose in PBS at $4^{\circ} \mathrm{C}$, embedded in OCT compound (Sakura Finetek), and cryosectioned at $14 \mu \mathrm{m}$. Sections were fixed in $4 \%$ paraformaldehyde in PBS, $\mathrm{pH} 7.2$ for $10 \mathrm{~min}$ at room temperature, followed by three 5 -min washes in DEPC-treated PBS. The sections were treated with $1 \mu \mathrm{g} / \mathrm{ml}$ Proteinase $\mathrm{K}$ in DEPC-PBS for $5 \mathrm{~min}$ at room temperature, followed by three 5-min washes in DEPC-PBS and re-fixation in $4 \%$ paraformaldehyde in $\mathrm{PBS}, \mathrm{pH} 7.2$ for $10 \mathrm{~min}$ at room 
temperature. Sections were acetylated in $0.25 \%$ acetic anhydride in $0.1 \mathrm{M}$ triethanolamine, $\mathrm{pH} 8.0$ for $10 \mathrm{~min}$ at room temperature, followed by three 5 -min washes in DEPC-PBS. Slides were incubated in hybridization buffer $(50 \%$ formamide, $5 \times$ SSC, $50 \mu \mathrm{g} / \mathrm{ml}$ Yeast tRNA, $100 \mu \mathrm{g} / \mathrm{ml}$ Heparin, $1 \times$ Denhardt's Solution, $0.1 \%$ Tween 20, 0.1\% CHAPS, $5 \mathrm{mM}$ EDTA) for $1-2 \mathrm{~h}$ at $65^{\circ} \mathrm{C} .100 \mu \mathrm{l}$ of digoxygenin-labeled probe $(1 \mathrm{mg} / \mathrm{ml})$ was added to each slide and the slides covered with glass coverslips. The slides were incubated in a chamber humidified with $5 \times$ SSC, $50 \%$ formamide at $65^{\circ} \mathrm{C}$ overnight. Coverslips were removed by rinsing in $0.2 \times$ SSC and the slides washed in $0.2 \times \mathrm{SSC}$ at $65^{\circ} \mathrm{C}$ for $1 \mathrm{~h}$. The slides were then washed in $0.2 \times \mathrm{SSC}$ for $5 \mathrm{~min}$ at room temperature, followed by another 5-min wash in $0.1 \%$ Tween-20 in PBS (PTw). The slides were blocked in $10 \%$ lamb serum in PTw at room temperature for $1 \mathrm{~h}$ and then stained with anti-digoxygeninalkaline phosphatase antibody $(1: 2000)$ for $1-3 \mathrm{~h}$ at room temperature in a humidified chamber. The slides were then washed three times for $5 \mathrm{~min}$ each in PTw and equilibrated with freshly-made alkaline phosphatase buffer (100 mM Tris $\mathrm{pH}$ 9.5, $50 \mathrm{mM} \mathrm{MgCl}_{2}, 100 \mathrm{mM} \mathrm{NaCl}, 0.1 \%$ Tween 20) for $10 \mathrm{~min}$. The slides were developed in alkaline phosphatase buffer containing $0.33 \mathrm{mg} / \mathrm{ml} \mathrm{NBT}$ and $0.18 \mathrm{mg} / \mathrm{ml} \mathrm{BCIP}$ in the dark at room temperature until the purple reaction product had developed to a satisfactory degree. The reaction was stopped by washing the slides in PBS three times for $15 \mathrm{~min}$ each, followed by fixation in $4 \%$ paraformaldehyde in PBS, $\mathrm{pH} 7.2$ for $30 \mathrm{~min}$. The slides were then rinsed and mounted in $80 \%$ glycerol in PBS. Whole mount in situ hybridization was carried out as recently described in detail (Khatri and Groves, 2013).

\section{RNA Isolation and Q-PCR}

For each experimental condition, total RNA was extracted from 4 uncultured whole cochlear explants or 3 cultured cochlear explants using the RNeasy mini kit (Qiagen). RNA yield ranged from 480 to $1200 \mathrm{ng}$ and was used for cDNA preparation using random primers and SuperScript III FirstStrand Synthesis System (Invitrogen). qPCR reaction was performed with SYBRGreen PCR Master Mix in StepOnePlus RealTime PCR System (Applied Biosystems), using in the reaction cDNA at $0.3-0.6 \mathrm{ng} / \mu \mathrm{l}$ and primers at $50 \mathrm{nM}$ (excepting $100 \mathrm{nM}$ for the Hes5 reaction). Primers sequences are provided in Table 1. GAPDH and $L 19$ primers were used as reference genes. Significant differences were analyzed using a MannWhitney test for pairwise comparisons. Multiple comparisons or pairwise correction for multiple comparisons were not performed.

\section{Single Cell Purification and Q-PCR Analysis}

Triple transgenic mice heterozygote for Fgfr3-iCreER ${ }^{T 2}$ (Young et al., 2010), Ai14:Rosa ${ }^{\text {tdTom }}$ (Jackson, \#007908) and Sox2-EGFP (Jackson, \#017592) were analyzed at $\mathrm{P} 2$, and double transgenic animals (Fgfr3-iCreER ${ }^{T 2}$ and Ai14:Rosa ${ }^{\text {tdTom }}$ ) were analyzed at P21. Animals were injected with $0.2 \mathrm{mg} / \mathrm{g}$ body weight tamoxifen at P0 and P19 respectively. Animals were euthanized 2 days after the
TABLE 1 | Q-PCR primers for Figures 1, 3, 5, 7

\begin{tabular}{|c|c|c|}
\hline Gene & Forward primer & Reverse primer \\
\hline Atoh1 & 5'-ATGCACGGGCTGAACCA-3' & $\begin{array}{l}\text { 5'-TCGTTGTTGAAGGAC } \\
\text { GGGATA-3' }\end{array}$ \\
\hline Notch1 & 5'-GCCGCAAGAGGCTTGAGAT-3' & $\begin{array}{l}\text { 5'-GGAGTCCTGGCATC } \\
\text { GTTGG-3' }\end{array}$ \\
\hline Notch3 & 5'-GCACTTGCCGTGGTTACATG-3' & $\begin{array}{l}\text { 5'-CCTCACAACTGTCACCAGC } \\
\text { ATAG-3' }\end{array}$ \\
\hline Hey1 & 5'-CACTGCAGGAGGGAAAGGTTAT-3' & $\begin{array}{l}\text { 5'-CCCCAAACTCCGATAG } \\
\text { TCCAT-3' }\end{array}$ \\
\hline Hey2 & 5'-AAGCGCCCTTGTGAGGAAA-3' & $\begin{array}{l}\text { 5'-TCGCTCCCCACGT } \\
\text { CGAT-3' }\end{array}$ \\
\hline HeyL & 5'-GCGCAGAGGGATCATAGAGAA-3' & $\begin{array}{l}\text { 5'-TCGCAATTCAGAAAGGC } \\
\text { TACTG-3' }\end{array}$ \\
\hline Hes5 & 5'-GCACCAGCCCAACTCCAA-3' & $\begin{array}{l}\text { 5'-GGCGAAGGCTाTGC } \\
\text { TGTGT-3' }\end{array}$ \\
\hline Jag1 & 5'-AAAGACCACTGCCGTACCAC-3' & $\begin{array}{l}\text { 5'-GGGGACCACAGACG } \\
\text { TTAGAA-3' }\end{array}$ \\
\hline $\operatorname{Jag} 2$ & 5'-TGCGAACTAGAGTACGACAA-3' & $\begin{array}{l}\text { 5'-TTGGTTCACAGAGAT } \\
\text { CCATG-3' }\end{array}$ \\
\hline DIl1 & 5'-TCCGATTCCCCTTCGGCTTCA-3' & $\begin{array}{l}\text { 5'-TCTGTTGCGAGGTCA } \\
\text { TCGGGA-3' }\end{array}$ \\
\hline DII3 & 5'-CCGCTITCCCAGACGCTGAT-3' & $\begin{array}{l}\text { 5'-GGCCTGGCCCGAAA } \\
\text { GAATGA-3' }\end{array}$ \\
\hline Gapdh & 5'-AGGTCGGTGTGAACGGATITG-3' & $\begin{array}{l}\text { 5'-TGTAGACCATGTAGTTGA } \\
\text { GGTCA-3' }\end{array}$ \\
\hline LI9 & 5'-GGTCTGGTTGGATCCCAATG-3' & $\begin{array}{l}\text { 5'-CCCGGGAATGGA } \\
\text { CAGTCA-3' }\end{array}$ \\
\hline
\end{tabular}

tamoxifen injection and organs of Corti were dissected. Single cell dissociation, flow cytometry, RNA isolation and single cell qRT-PCR were performed as described in Durruthy-Durruthy et al. (2014) using the primers listed in Table 2. Briefly, expression of Actb or Gapdh at levels lower or higher than 3 standard deviations from the mean was used to exclude compromised cells/empty wells or possible doublets, respectively. Ai14-Control primers detect recombination within the Ai14-tdTomato reporter locus and cells with no detectable recombination were excluded from the analysis. Single cell expression data is presented as $\log 2 \mathrm{Ex}$ values, calculated by subtracting experimentally determined Ct-values from the median limit of detection calculated for all primers used in the study. Single cell data were normalized using the median Log2Ex values as recommended by Fluidigm.

\section{Noise Damage}

Noise damage of six-week-old CBA/CaJ mice was performed as previously described (Liu et al., 2011). Briefly, a custom-built box contained six piezo horns (TW-125, Pyramid Car Audio, Brooklyn, NY, USA) inserted through the cover. Band-passed white noise (4-22 kHz) was generated digitally with RPvds software (Version 6.6, Tucker-Davis Technologies, Alachua, FL, USA), converted to analog by a digital-to-analog converter, and then transferred to the power amplifier (Servo 550, Sampson, Hauppauge, NY, USA) to drive the speakers. A cage containing the mice was placed inside the box and the mice were exposed to noise at $98 \mathrm{~dB} \pm 2 \mathrm{~dB}$ for $4 \mathrm{~h}$ 
TABLE 2 | Q-PCR primers for Figure 6

\begin{tabular}{|c|c|c|}
\hline Gene & Forward primer & Reverse primer \\
\hline Actb: & 5'- CCCTAAGGCCAACCGTGAAA -3' & $\begin{array}{l}5^{\prime} \text { - CAGCCTGGATG } \\
\text { GCTACGTAC - } 3^{\prime}\end{array}$ \\
\hline Gapdh & 5'- AGACGGCCGCATCTTCTT -3' & $\begin{array}{l}5^{\prime}-\text { TTCACACCGACC } \\
\text { TTCACCAT - } 3^{\prime}\end{array}$ \\
\hline Ai9-Control & 5' - AGGAACTTCGTCGACATTTAAATCA -3' & $\begin{array}{l}5^{\prime} \text { - CTGCAGGTCGA } \\
\text { GGGACCTAA - } 3^{\prime}\end{array}$ \\
\hline Fgfr3 & 5' - AGGATTTAGACCGCATCCTCAC -3' & $\begin{array}{l}\text { 5'- CCTGGCGAGTAC } \\
\text { TGCTCAAA - } 3^{\prime}\end{array}$ \\
\hline Cdkn1b & 5' - CAGTGTCCAGGGATGAGGAA -3' & $\begin{array}{l}5^{\prime}-\text { TTCGGGGAACCGTC } \\
\text { TGAAA -3' }\end{array}$ \\
\hline Sox2 & 5'- TGAAGGAGCACCCGGATTATA -3' & $\begin{array}{l}\text { 5'- CGGGAAGCGTGT } \\
\text { ACTTATCC -3' }\end{array}$ \\
\hline Jag1 & 5' - AACGACCGTAATCGCATCGTA -3' & $\begin{array}{l}5^{\prime} \text { - TCCACCAGCAAAGT } \\
\text { GTAGGAC - } 3^{\prime}\end{array}$ \\
\hline Jag2 & 5' - CTCGTCGTCATTCCCTITCA -3' & $\begin{array}{l}\text { 5'- GGTGTCATTGTC } \\
\text { CCAGTCC - } 3^{\prime}\end{array}$ \\
\hline Hes1 & 5' - TGAAGCACCTCCGGAACC -3' & $\begin{array}{l}5^{\prime} \text { - CGCGGTATTTCC } \\
\text { CCAACAC - } 3^{\prime}\end{array}$ \\
\hline Hes5 & 5' - AAGAGCCTGCACCAGGACTA -3' & $\begin{array}{l}\text { 5'- GTGCAGGGTCAGG } \\
\text { AACTGTAC - } 3^{\prime}\end{array}$ \\
\hline Hey1 & 5' - ACGAGACCATCGAGGTGGAA -3' & $\begin{array}{l}5^{\prime} \text { - CGTTGGGGACAT } \\
\text { GGAACACA - } 3^{\prime}\end{array}$ \\
\hline Hey2 & 5' - ACTAGTGCCAACAGCTITGAA -3' & $\begin{array}{l}5^{\prime}-\text { TGTAGCCTGGAGC } \\
\text { ATCTTCA -3' }\end{array}$ \\
\hline LFng & 5' - TCGATCTGCTGTTCGAGACC -3' & $\begin{array}{l}5^{\prime}-\text { CCTCCCCATCAG } \\
\text { TGAAGATGAA - } 3^{\prime}\end{array}$ \\
\hline
\end{tabular}

\section{Results}

\section{The Neonatal Cochlea Exhibits a Position-Dependent Variation of Supporting Cell Trans-Differentiation in Response to Gamma Secretase Inhibitors}

A number of studies have demonstrated conversion or transdifferentiation of cochlear supporting cells into hair cells after treatment with gamma secretase inhibitors (Takebayashi et al., 2007; Hayashi et al., 2008; Doetzlhofer et al., 2009; Korrapati et al., 2013; Mizutari et al., 2013; Bramhall et al., 2014), although results in different studies have often been obtained with different gamma secretase inhibitors or at different concentrations of a given inhibitor. We confirmed these results in cochlear explant cultures from postnatal day 0 (P0) Atoh1 $1^{\mathrm{AlGFP} / \mathrm{AlGFP}}$ and Atoh1-GFP mice, using the gamma secretase inhibitor DAPT over a range of $0.75-10 \mu \mathrm{M}$. After 2 days in culture, we stained the cultures for Myosin VIIa and GFP to reveal the Atoh1-GFP fusion protein

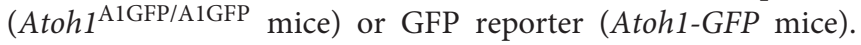
We observed a significant increase in the numbers of Myosin VIIa + hair cells at $2.5,5$ and $10 \mu \mathrm{M}$ DAPT compared to DMSO vehicle (Figures 1A,B), but not at lower concentrations. We measured the levels of hair cell and supporting cell mRNAs in the Atoh1-GFP cultures and observed an increase of the hair cell markers Atoh1 and Jag2 and a decrease in the supporting cell markers Jag1, Hey1 and Hes5 (Figure 1C). As previously described (Doetzlhofer et al., 2009), Hes5 was particularly sensitive to DAPT, with a strong reduction in mRNA levels being observed above $1 \mu \mathrm{M}$.

The organ of Corti differentiates in a broadly basalapical direction, with the first differentiating Atoh $1^{+}$hair cells appearing near the base of the cochlea, and a wave of hair cell and supporting cell differentiation spreading basally to the hook region and in an apical direction to the tip of the cochlea (Chen et al., 2002; Cai et al., 2013). Consequently at birth, hair cells and supporting cells in the basal region of the cochlea can be considered to be slightly more mature than their counterparts at the apex and tip. To determine whether these differences in maturity affected the response to gamma secretase inhibitors, we cultured whole P0 cochleas from Atoh1-GFP mice in $10 \mu \mathrm{M}$ DAPT or DMSO vehicle for 1-3 days and counted the numbers of Atoh1-GFP or Myosin VIIa-expressing hair cells in the apical, middle and basal regions of the cochlea (Figures 2A,B; the approximate positions of the three regions are indicated in Figure 2C). We excluded from our counts the most basal hook region as it was more susceptible to variable damage during dissection and the most apical tip region because of its more variable behavior. We observed a clear effect of position on the number of supernumerary hair cells generated in the cultures over the 3 day culture period, with the apex producing $202 \%$ more hair cells after 3 days, whereas the base generated only $32 \%$ more hair cells in the same time period (Figures 2A,B). These results suggested that more mature supporting cells at the base of the cochlea were far less likely to trans-differentiate into hair cells in response to DAPT than their younger counterparts at the apex.

\section{The Response of Supporting Cells to Gamma Secretase Inhibition or Notch Inhibition Declines Rapidly with Age}

To test whether the response of cochlear supporting cells to DAPT was indeed age-dependent, we established cochlear cultures from newborn (P0), 3 and 6 day old mice and cultured them for 2 days in $5 \mu \mathrm{M}$ DAPT. We quantified the number of supernumerary hair cells in the apical region. We saw significant numbers of supernumerary hair cells in DAPT-treated P0 cochlear cultures compared to DMSO vehicle, but observed no significant increase in hair cell numbers when either P3 or P6 cultures were treated with DAPT (Figures 3A,B).

Most experiments in which gamma secretase inhibitors have been used to promote supporting cell trans-differentiation into hair cells are interpreted on the assumption that the inhibitors are targeting the cleavage of Notch receptors in cochlear supporting cells. However, since gamma secretases cleave many other membrane proteins (Kopan and Ilagan, 2004), it is possible that some of the effects of gamma secretase inhibitors may be due to the inhibition of cleavage of other membrane proteins. To test this, we used specific blocking antibodies to the Notch1 receptor (Wu et al., 2010) at a concentration of $2 \mu \mathrm{g} / \mathrm{ml}$, previously shown to effectively inhibit Notch1 signaling in vitro (Wu et al., 2010). Cochlear cultures from P0 animals showed similar age-dependent responses to Notch1 blocking antibodies (48\% 
A

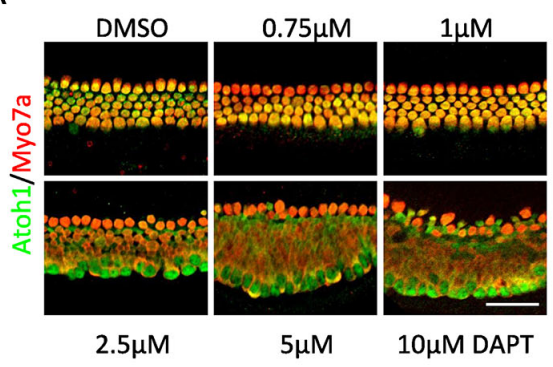

B

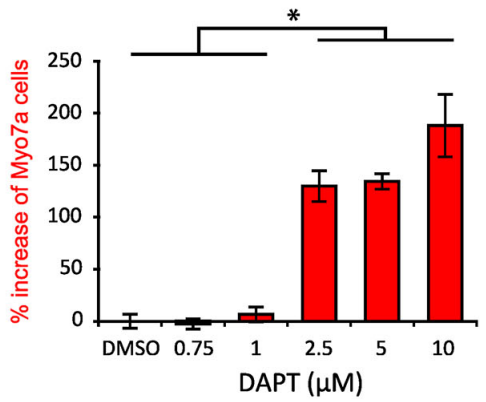

C

Atoh1
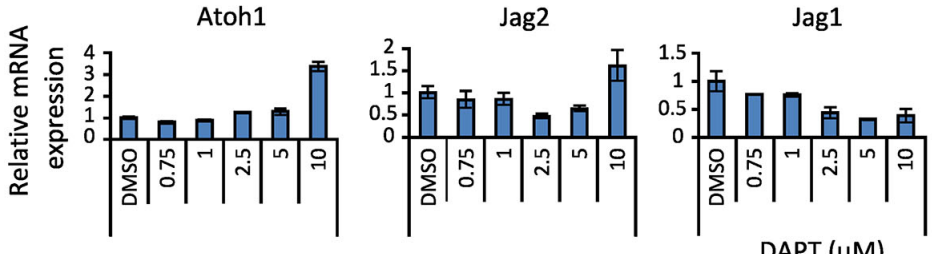

DAPT $(\mu \mathrm{M})$
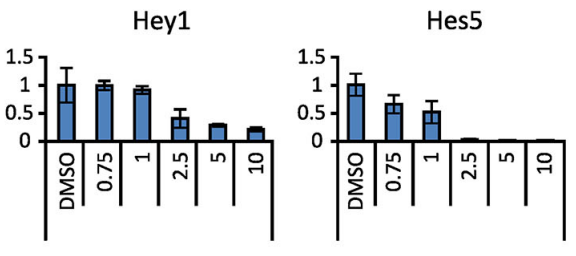

FIGURE 1 | Dose response of Notch inhibition in P0 cultures.

(A) Immunostaining of apical portions of cochlear explants of newborn (PO) Atoh1A1GFP/A1GFP knock-in mice cultured 2 days in vitro (DIV) in DAPT from 0.75 to $10 \mu \mathrm{M}$ or vehicle (DMSO). Atoh1: green. Myo7a: red. Scale $50 \mu \mathrm{m}$.

(B) Quantitation of the increase in number of Myosin Vlla-labeled cells after different doses of DAPT compared to DMSO vehicle (same as shown in $\mathbf{A}$ ).
$N=4$. ${ }^{*} p=0.030$ (Mann-Whitney pairwise comparisons). Error bars: SEM. (C) mRNA amount of hair cell, supporting cell and Notch pathway genes obtained by QPCR in whole cochlear explants from PO Atoh1 1 GFP transgenic reporter mice treated with DAPT compared to DMSO vehicle. $N=3$. Error bars: SEM. Note that error bars are present for each condition but are very small in some cases.

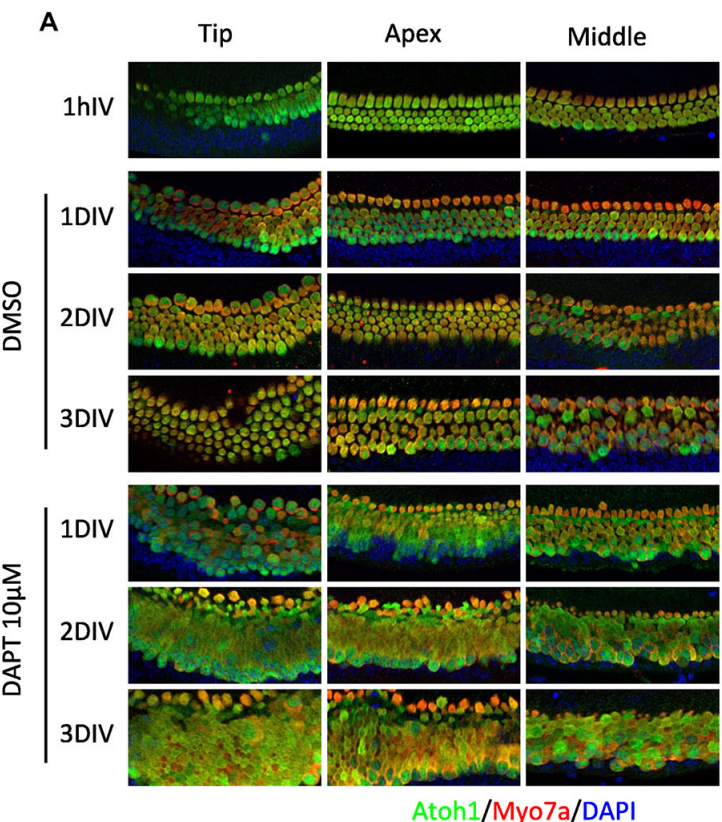

FIGURE 2 | Position-dependent effect of Notch inhibition in PO cultures. (A) Immunostaining of different cochlear portions from newborn (P0) Atoh 1 ${ }^{\text {A1GFP/A1GFP }}$ knock-in mice (shown in C) treated with $10 \mu \mathrm{M}$ DAPT or vehicle (DMSO) for $1 \mathrm{~h}$ to 3 days in vitro (DIV). Atoh1: green. Myo7a: red. DAPI: Blue. (B) Percentage of increase in numbers of

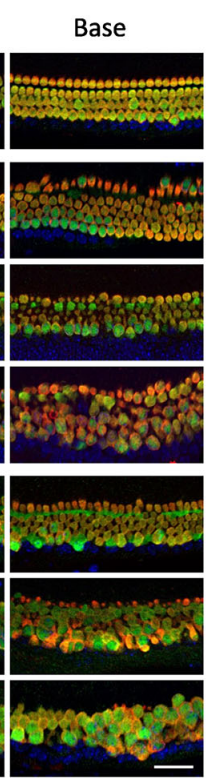

B
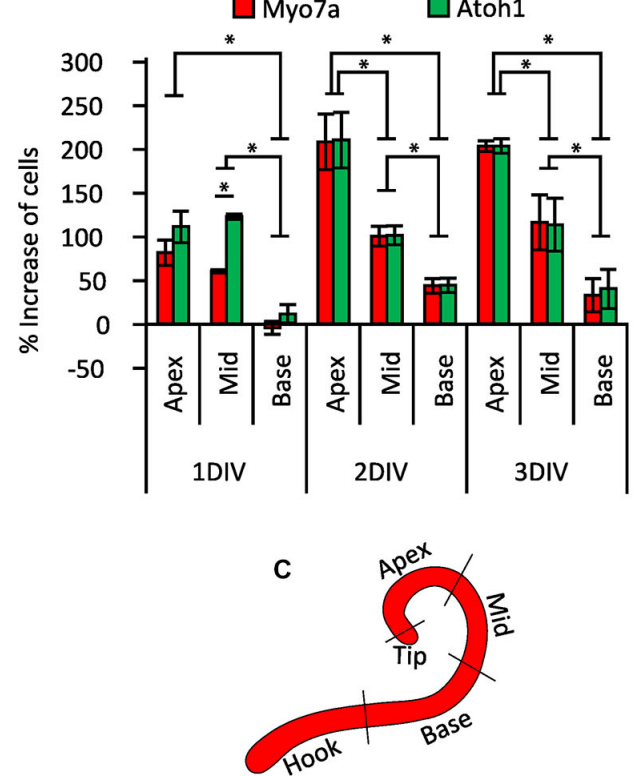

increase in Myosin VIIa ${ }^{+}$hair cells) as cultures incubated for 2 days in $5 \mu \mathrm{M}$ DAPT ( $41 \%$ increase) compared to control
Myosin VIla-labeled cells and GFP-labeled cells in the different regions of the cochlea after DAPT $10 \mu \mathrm{M}$ treatment compared to vehicle (same as shown in A). $N=4 .{ }^{*} P=0.030$ (Mann-Whitney pairwise comparisons). Error bars: SEM. (C) Schematic view of the cochlear portions evaluated in $(\mathbf{A}, \mathbf{B})$ cultures containing DMSO or a control IgD (Figures 3A,B). However, we saw no significant response when P3 or P6 
A

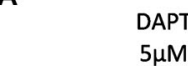
$5 \mu \mathrm{M}$

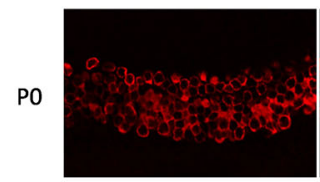

P3

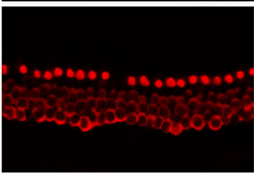

P6

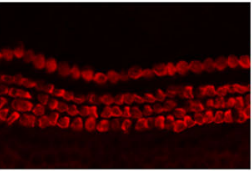

Anti Notch1

$2 \mu \mathrm{g} / \mathrm{ml}$
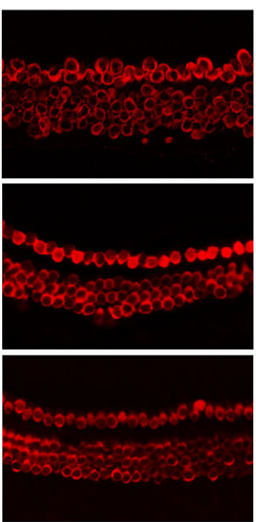

IgD Control $2 \mu \mathrm{g} / \mathrm{ml}$
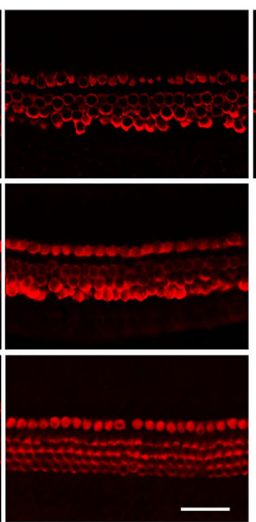

B

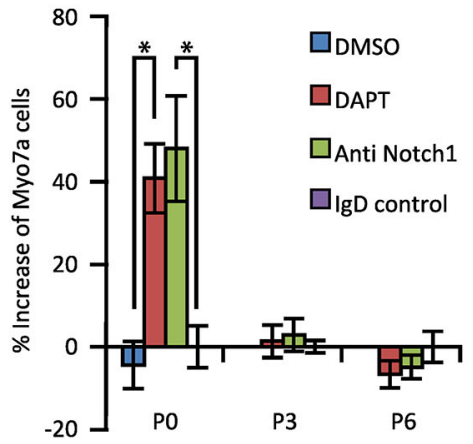

C

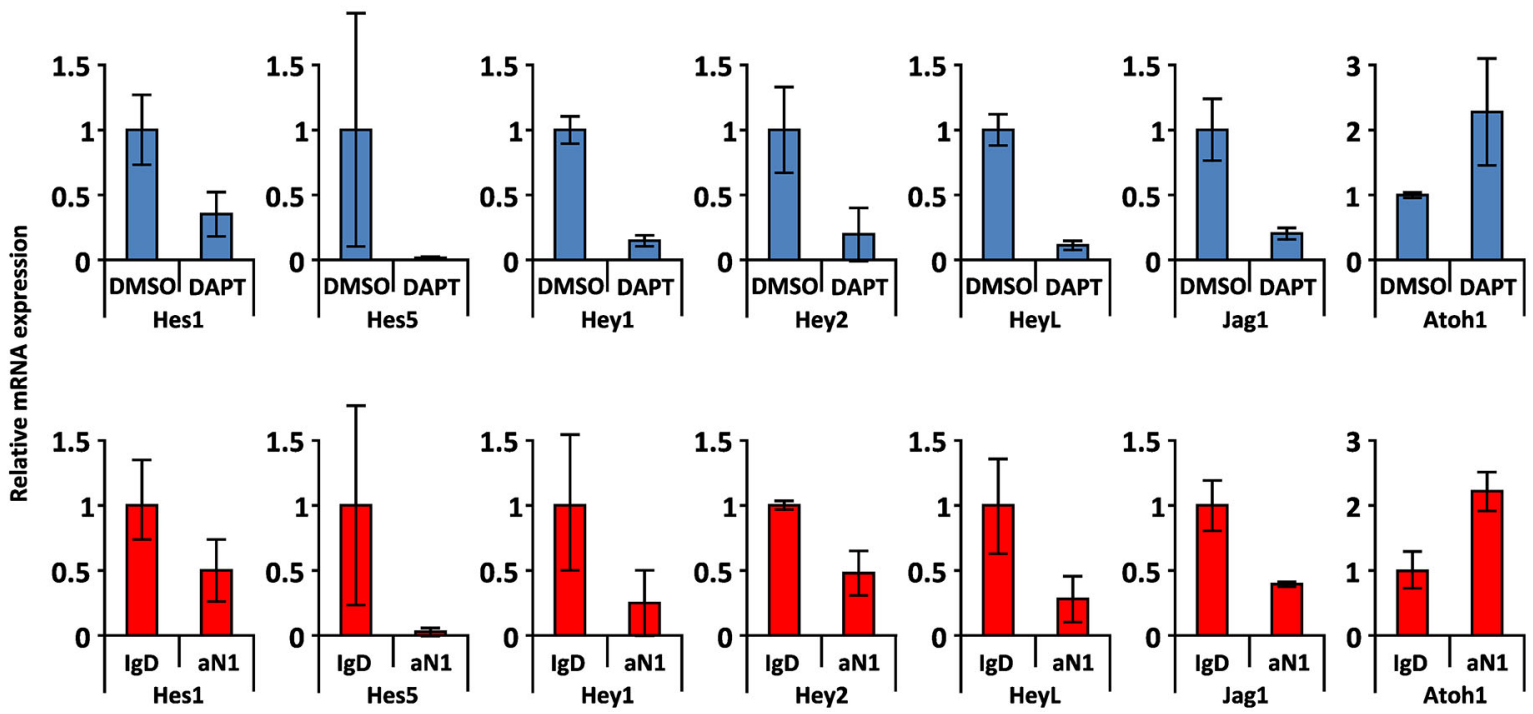

FIGURE 3 | Age-dependent decline in the effect of Notch inhibition on supporting cells in the presence of gamma secretase inhibitors or Notch1 blocking antibodies. (A) Immunostaining of apical portions of cochlear explants obtained at 0,3 and 6 postnatal days (P0, P3 and P6) from Atoh ${ }^{\text {GFP }}$ transgenic reporter mice treated with $5 \mu \mathrm{M}$ DAPT, $2 \mu \mathrm{g} / \mathrm{ml}$ Notch1 antibodies (Anti Notch1), $2 \mu \mathrm{g} / \mathrm{ml}$ control lgD and DMSO cultured 2 days in vitro (DIV). Myo7a: red. Scale $50 \mu \mathrm{m}$. (B) The increase in numbers of Myosin Vlla-labeled cells in the apical portion of the cochleas shown in (A). $N=6,6$ and 3 for PO, P3 and P6 respectively. ${ }^{*} p=0.0044$ and 0.0045 for DMSO/DAPT and
Anti Notch1/Control lgD comparisons respectively (Mann Whitney). Error bars: SEM. (C) mRNA amount of Notch pathway genes obtained by QPCR in whole cochlear explants of Atoh $1^{\text {GFP }}$ transgenic reporter P0 newborn mice cultured in the presence of DAPT or DMSO and in Notch1 antibodies or control lgD antibodies. Blue columns (top): level of expression after DAPT treatment relative to DMSO. Red columns (bottom): level of expression after anti Notch1 antibodies (aN1) relative to control IgD antibodies. $N=3$. Error bars: SEM. Note that error bars are present for each condition but are very small in some cases. cultures were treated with blocking antibodies as we previously saw with $5 \mu \mathrm{M}$ DAPT (Figures 3A,B). We also observed a comparable down-regulation of supporting cell-specific Hes and Hey genes and the supporting cell marker Jag1 in P0 cultures treated with DAPT or Notch1 blocking antibodies, together with a comparable up-regulation of Atoh1 (Figure 3C). These results suggest that the majority of the effects of the gamma secretase inhibitor DAPT on supporting cell transdifferentiation in neonatal cultures are likely specific to the Notch pathway.

\section{Notch Pathway Genes are Down-Regulated in the Cochlea During the First Postnatal Week}

The preceding results suggest that the Notch pathway is deployed to stabilize supporting cell fate of neonatal cochlear supporting cells, but that inhibition of the Notch pathway has no effect on supporting cell fate even a few days later. To determine out if this change in the response of supporting cells to Notch inhibition was related to changes in the endogenous activity of the Notch pathway, we examined the expression of mRNA for Notch receptors (Notch1 and Notch3), ligands (Dll1, Jag1 


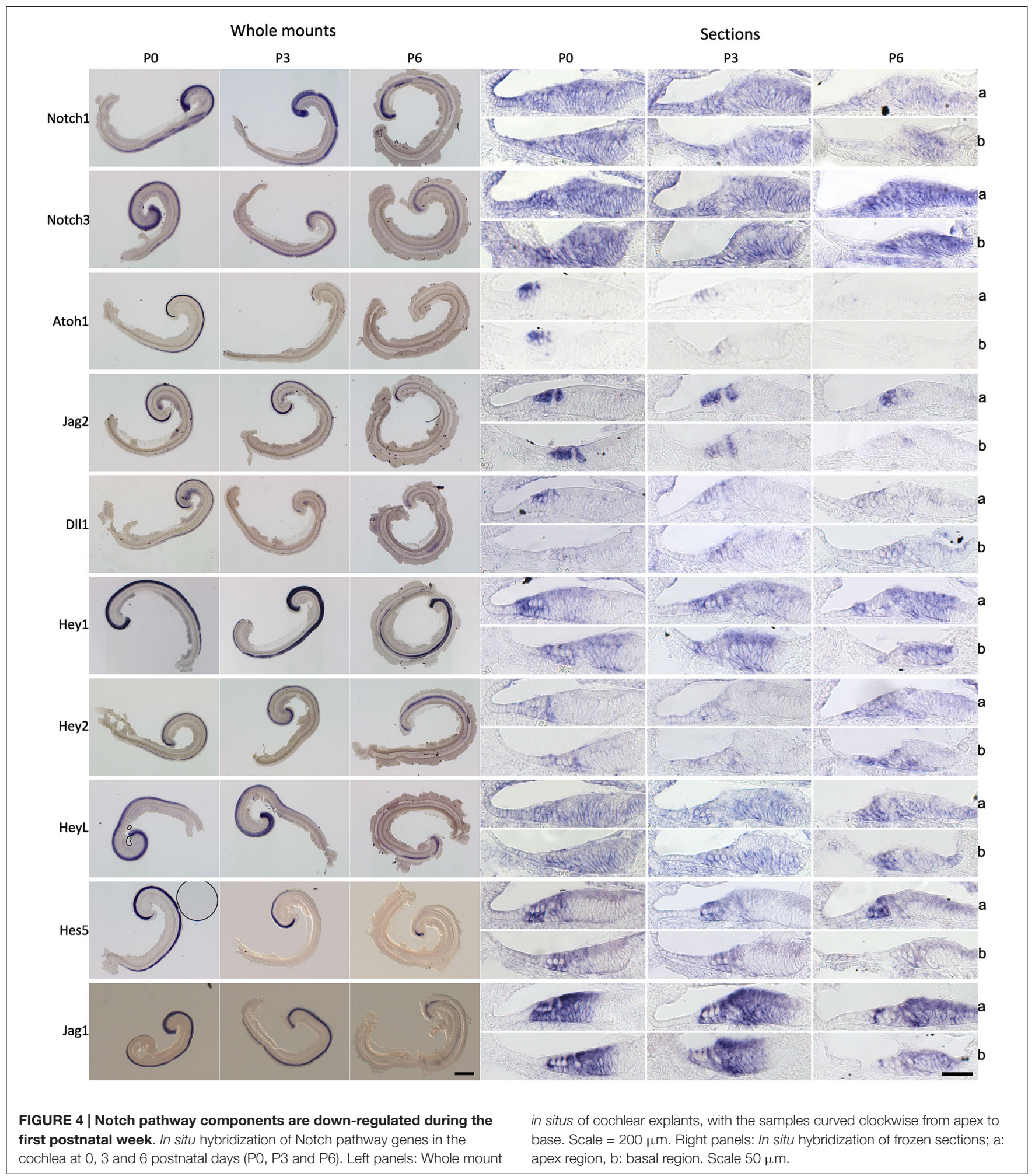

and Jag2) and downstream effectors of Notch signaling (Hey1, Hey2, HeyL and Hes5) in the cochlea from P0 to P6 by in situ hybridization on whole mount cochleas, sectioned cochleas and by Q-PCR of cochlear tissue (Figures 4, 5A). In general, all components of the Notch pathway evinced a down-regulation between P0 and P6 starting at the base and proceeding down to the apex. Specifically, Notch1 and Notch3 were expressed throughout the supporting cell layer and into Kölliker's organ 


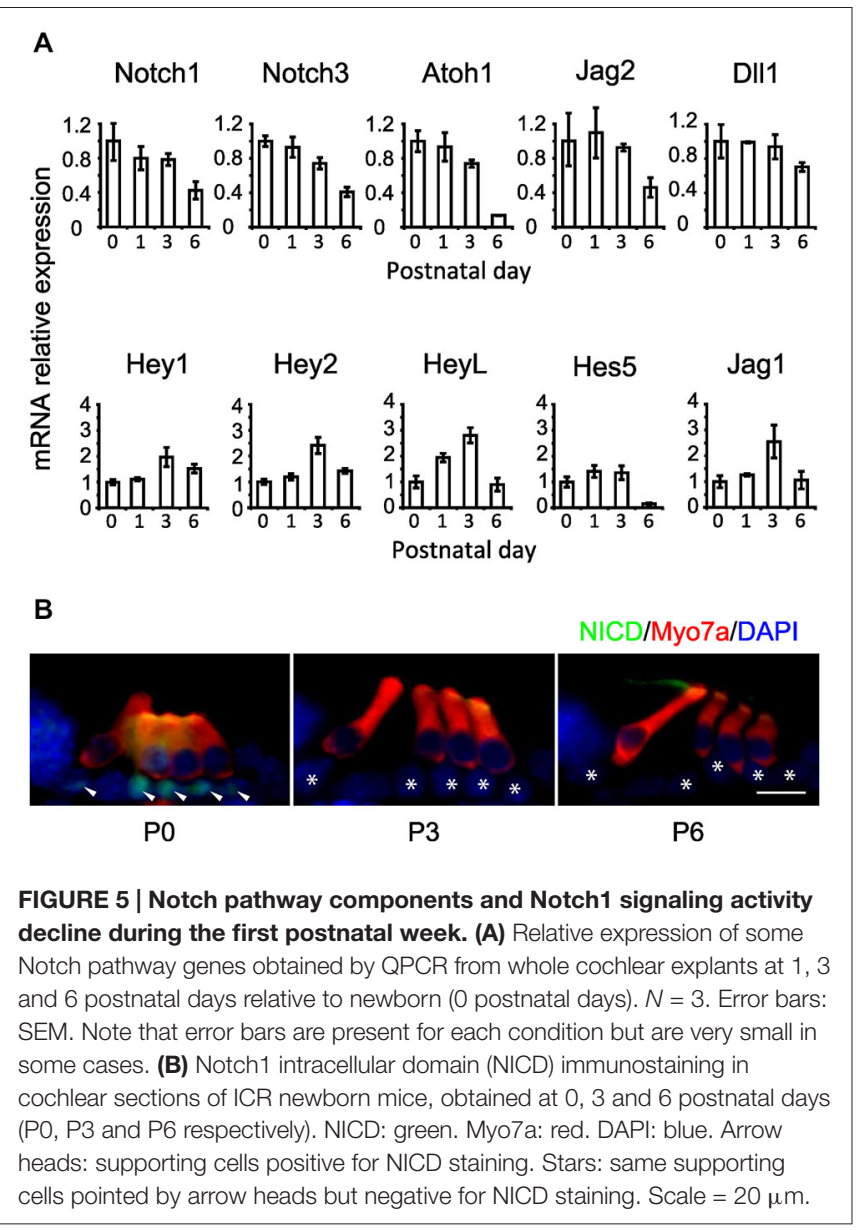

and the outer sulcus, and both receptors showed a basal-apical down-regulation between P0 and P6. Jag2 and Dll1 were both down-regulated in hair cells between $\mathrm{P} 0$ and $\mathrm{P} 6$, along with the hair cell marker Atoh1. Hey2 and Hes5 were down-regulated from pillar cells and Deiters' cells respectively in a basal-apical gradient, whereas Heyl, HeyL and Jag1 were expressed in all supporting cells and cells of Kölliker's organ, and down-regulated again in a basal-apical direction. The speed of down-regulation varied considerably from gene to gene-for example, Dll1 was down-regulated in hair cells more quickly than Jag2, and Hes5 was down-regulated much more quickly in supporting cells than Hey1. We also saw a general trend towards down-regulation of each gene by Q-PCR (Figure 5A), although the degree of downregulation measured by this method was somewhat blunted as a result of including the entire basal-apical extent of the cochlear duct in each sample. To confirm that activation of the Notch1 receptor was also decreasing between P0 and P6, we immunostained cochlear sections with antibodies to the Notch1 intracellular domain (Notch1-ICD) which is released and localized to the nucleus after Notch activation (Figure 5B). We observed Notch1-ICD staining in Deiters' cells at P0, but could not detect staining in the supporting cells at later stages.

Although we did not see a significant increase in hair cells numbers at P3 or P6 after Notch inhibition in culture we did observe occasional isolated ectopic hair cells in our P3 (but not P6) cultures that may have been generated by transdifferentiation of supporting cells (Figures $3 \mathbf{A}, \mathbf{B}$ ) raising the possibility that a sub-population of supporting cells maintain Notch pathway expression at significant levels. To test whether small numbers of mature supporting cells maintain expression of some Notch pathway genes, we used the Fluidigm single cell handling system to compare gene expression in individual supporting cells purified from P2 and P21 mice. To label and purify pillar cells and Deiters' cells at P2, we injected triple transgenic mice (FGFR3-iCreERT2/Ai14:Rosa ${ }^{\text {tdTom}} /$ Sox2EGFP) with tamoxifen at P0 and isolated TdTomato/EGFP double positive cells by flow cytometry. At this age, FGFR3iCreERT2 fate-labels pillar, Deiters', and outer hair cells, whereas EGFP is confined to all supporting cells. At P21, we used double transgenic (FGFR3-iCreERT2/Ai14:Rosa ${ }^{\text {tdTom }}$ ) mice, injected with tamoxifen at P19, and sorted TdTomato-positive pillar and Deiters' cells, which were the only organ of Corti cell types labeled at this age. cDNA was prepared from individual P2 $(N=162)$ and P21 $(n=123)$ TdTomato cells using the Fluidigm single cell analysis system, and 96 genes analyzed from each sample by Q-PCR, including the Notch pathway genes Jag1 and 2, Hes1 and 5, Hey1 and 2, and the Notch target and ligand modulator LFng (Figure 6). In all cases, the numbers of cells with detectable amounts of Notch pathway genes declined from P2 to P21, (Figure 6A). The distribution in expression levels of Notch pathway genes in individual cells was visualized in violin plots and revealed a clear downward shift in expression across the population from P2 to P21 (Figure 6B), even when cells with undetectable levels of expression were removed from the analysis (Figure $\mathbf{6 C}$ ). In some cases, we saw evidence for a small population of cells expressing high levels of a single Notch pathway gene at P21 (e.g., Jag2; Figure 6C), but we were unable to observe any single cells at P21 that co-expressed high levels of multiple Notch genes. These data suggest that the majority of P21 FGFR3-iCreERT2 fate labeled supporting cells are unlikely to be transducing significant Notch signaling.

\section{Notch Pathway Components are not Expressed at Significant Levels in the Normal and or Noise-Damaged Adult Organ of Corti}

Several previous studies have suggested that some components of the Notch pathway may be re-activated in supporting cells following damage (Oesterle et al., 2008; Batts et al., 2009; Mizutari et al., 2013). However, these studies did not perform a direct quantitative comparison of message levels of Notch pathway components between neonatal animals (in which the Notch pathway is expressed and active) and mature animals before and after damage. We examined the expression of Atoh 1 and Hes 5 in cochleas isolated from cohorts of mice which received noise damage at P42 and were analyzed at one, three, or seven days later. Our controls were non-noise exposed cohorts of P0 and P49 mice. The level of noise we applied has been shown to be adequate to damage the cochlear epithelium and elicit changes in gene expression. In particular, it produces large temporary threshold 
A

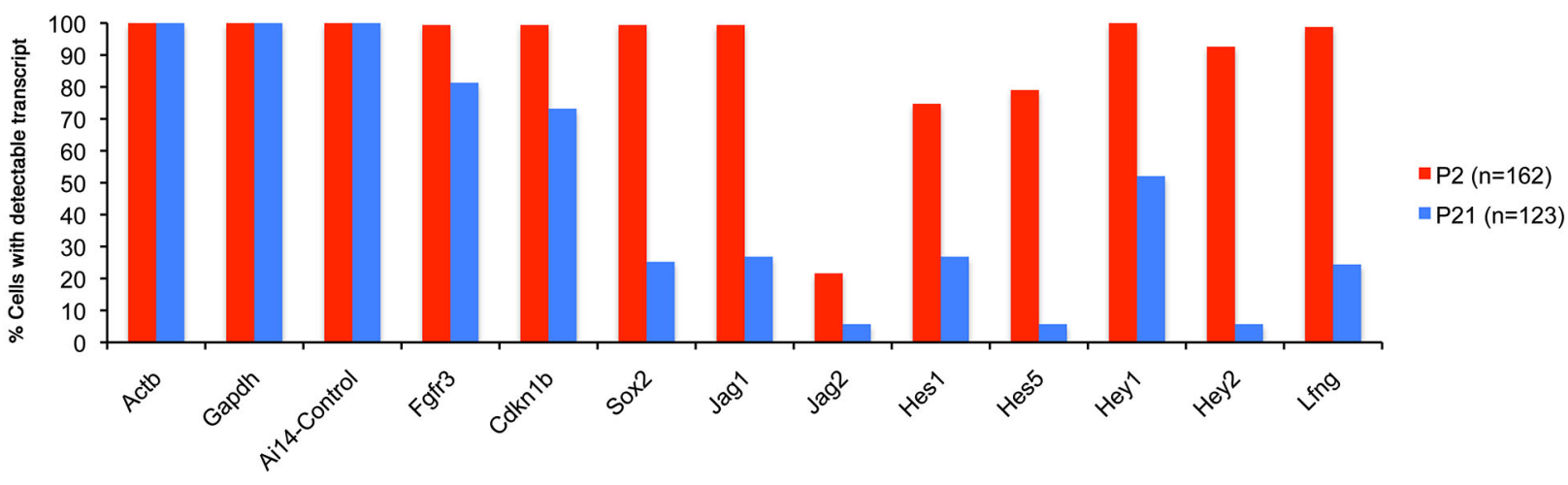

B

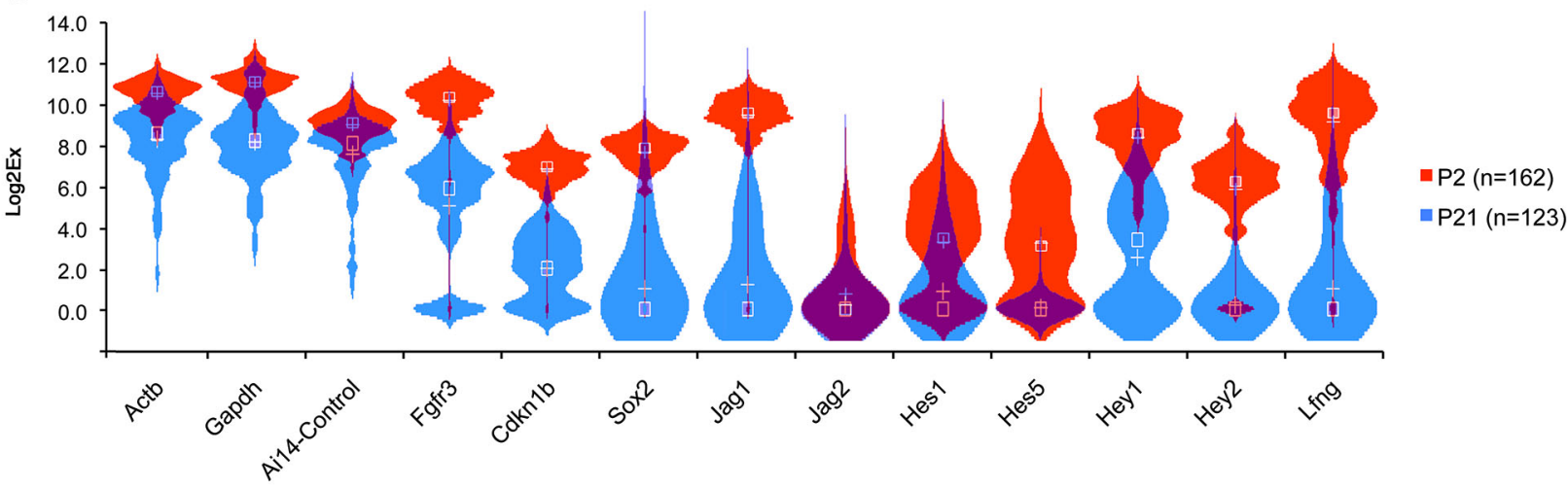

C

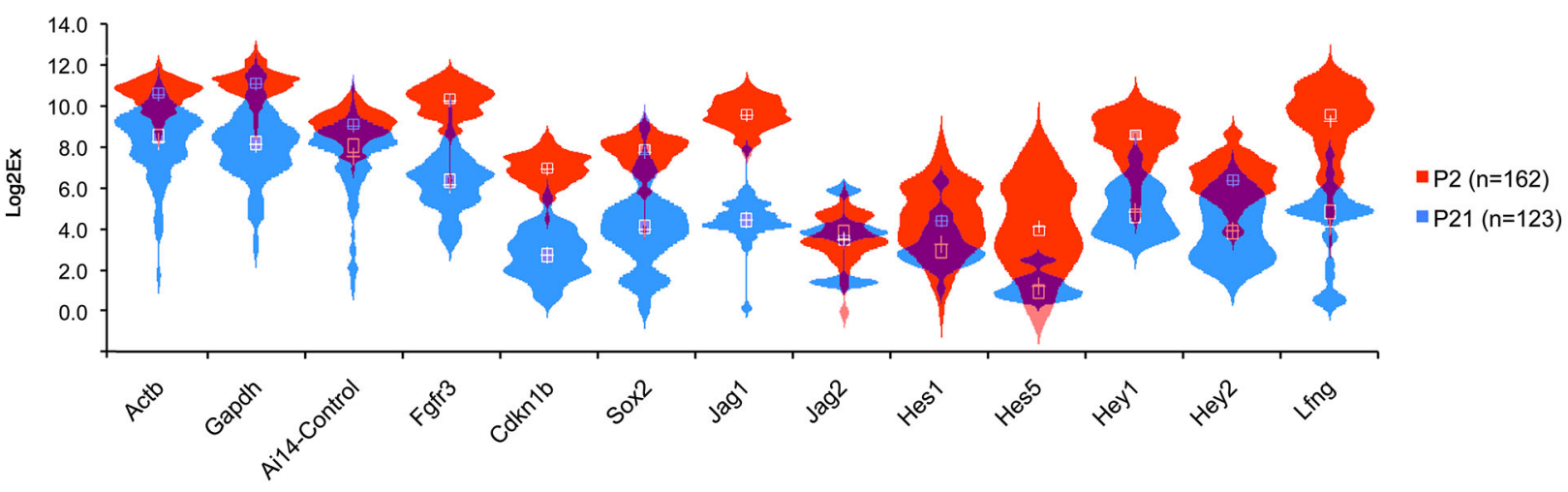

FIGURE 6 | Comparison of Notch pathway genes in P1 and P21 cochlea at the single cell level. Pillar and Deiters' cells were purified from P2 and P21 FGFR3-CreER;ROSA-TdTomato mice and RNA extracted from 162 (P2) and 123 (P21) single cells and subjected to QPCR analysis using the Fluidigm system (Durruthy-Durruthy et al., 2014) with primers for housekeeping genes and Notch pathway genes. (A) Graph showing the percentage of cells at each age that expressed detectable levels of each gene under analysis. (B) Violin plot showing the distribution of expression levels for each gene in all cells including the cells with no expression ( $\log 2 x=0)$ presented in a combination of box plots and kernel density plots. White Crosses indicate the mean, white boxes the median expression levels. (C) Violin plot similar to (B), excluding cells with undetectable levels of expression for each gene. elevations, and mild permanent threshold shifts, $17 \%$ OHC loss and 3\% IHC loss, and increases in prestin gene expression in residual OHCs (Wang et al., 2010; Xia et al., 2013). We found that levels of the hair cell-specific transcription factor Atoh 1 in 7 week old animals were less than $10 \%$ of their neonatal counterparts (Figure 7) and that these levels did not change significantly over a 7 day period after noise damage. Similar results were observed for Hes5 (Figure 7). These data suggest that the Notch pathway remains down-regulated in the mature cochlea and that it is not significantly perturbed by noise damage.

\section{Discussion}

The Notch signaling pathway is deployed during the differentiation of hair cells and supporting cells and has been proposed to regulate the proportion of each cell type 

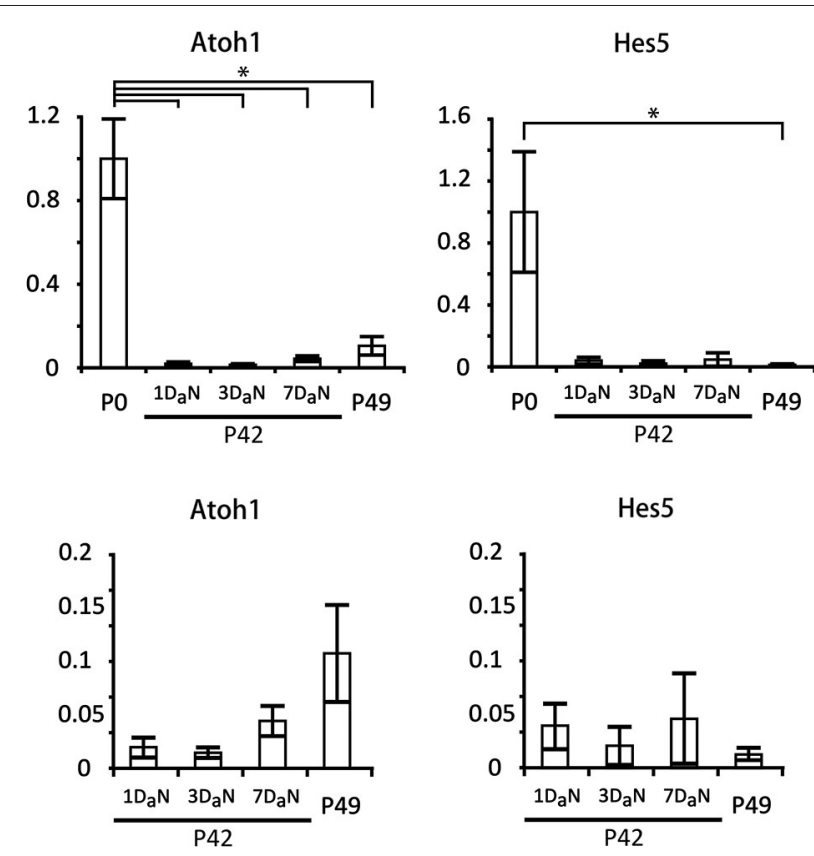

FIGURE 7 | Hes5 and Atoh1 remain expressed at very low levels in the mature organ of Corti, even after noise damage. Relative expression of Atoh1 and Hes5 obtained by QPCR in cochlear explants from neonatal (PO) and 6 to 7 week old mice exposed to noise. The mice exposed to noise on the 42nd postnatal day (P42) were evaluated after $1\left(1 D_{a} N\right), 3\left(3 D_{a} N\right)$, or 7 $\left(7 \mathrm{D}_{a} \mathrm{~N}\right)$, days. As controls for the 7 day cohort we used 7 week old mice (P49) that had never been exposed to noise. The expression levels of Atoh1 and Hes5 were normalized to the level of expression at PO. $N=3$ in all cases except PO, where $N=6$. The values for adult animals are re-plotted on separate graphs; note that no significant changes occur in the adult samples. Error bars: SEM. ${ }^{*} p=0.03689$ (Mann-Whitney pairwise comparisons).

through lateral inhibition (Lewis, 1991; Eddison et al., 2000). The observation that inhibiting Notch signaling can generate ectopic hair cells at the expense of supporting cells (Takebayashi et al., 2007; Hayashi et al., 2008; Doetzlhofer et al., 2009; Korrapati et al., 2013; Mizutari et al., 2013; Bramhall et al., 2014), together with the observation that Notch signaling is re-deployed during avian hair cell regeneration (Stone and Rubel, 1999; Stone and Cotanche, 2007) has raised the possibility of targeting the Notch pathway in the damaged cochlea to effect hair cell replacement. However, results with Notch inhibitors in the adult cochlea have given variable results (Hori et al., 2007; Mizutari et al., 2013; Tona et al., 2014), prompting us to examine how this pathway is regulated as the cochlea matures. We show that the response of supporting cells to Notch inhibition drops dramatically in the first postnatal week, concomitant with a down-regulation of many components of the Notch signaling pathway.

Many studies have used gamma secretase inhibitors as a reagent to inhibit Notch signaling, despite the fact that gamma secretases are known to cleave scores of other transmembrane proteins in addition to Notch receptors (Kopan and Ilagan, 2004). Although it has generally been assumed that the conversion of supporting cells to hair cells in the presence of gamma secretase inhibitors is due to Notch inhibition, very few studies have tested this formally (Hayashi et al., 2008). We now show that the effects of the gamma secretase inhibitor DAPT on perinatal cochlear cultures-both in terms of the numbers of ectopic hair cells generated, in the down-regulation of Notch target genes and in the age-dependent response to these inhibitors - can be mimicked by blocking antibodies to the Notch1 receptor. While it remains formally possible that other gamma secretase-dependent signaling pathways are operating in perinatal supporting cells, our data suggest that the effect of inhibiting such pathways is negligible compared to their effect on Notch cleavage. We saw no evidence for supporting cell proliferation in our neonatal cultures treated with DAPT or Notch blocking antibodies (Doetzlhofer et al., 2009; data not shown). Conditional deletion of the Notch1 receptor, either at the otic placode stage (Kiernan et al., 2005a) or in neonatal mice (Li et al., 2015) has been reported to cause a small amount of supporting cell proliferation. Since these studies were both performed in intact animals, it is possible that the conditions used to establish organ cultures in our study militate against supporting cell proliferation when Notch signaling is blocked. Alternatively, it is possible that loss of a single allele in the Sox2-CreER and Foxg1-Cre knock-in lines used in these studies may interact genetically with Notch1 mutants to cause abnormal proliferation. Indeed, haploinsufficiency of Sox 2 can modify the phenotype of $p 27^{K i p 1}$ mutants (Li et al., 2012), and Foxg1-Cre knock-in mice have been shown to have brain defects associated with proliferative defects on certain genetic backgrounds (Shen et al., 2006; Eagleson et al., 2007; Siegenthaler et al., 2008; see Cox et al., 2012 for further discussion).

We have characterized an age-dependent decline in the response of cochlear supporting cells to Notch inhibition in two ways. Our results from the most direct test of such agedependence-treating cochlear tissue of different ages with Notch inhibitors (Figure 3)-are also supported by a careful analysis of basal-apical differences in the response of neonatal cochlear cultures to Notch inhibitors (Figure 2). Since hair cells and supporting cells in the mid-base of the cochlea differentiate at least 3 days before cells at the apex (Chen et al., 2002; Cai et al., 2013), analysis of whole cochlear explants allows us to directly compare different states of supporting cell differentiation in the same tissue. In P0 mice, we saw a higher proportion of ectopic outer hair cells vs. inner hair cells in the apex of the cochlea, and an even smaller proportion of ectopic inner hair cells at the base. Since inner hair cells begin to differentiate before outer hair cells in any given region of the cochlea (Chen et al., 2002; Cai et al., 2013), it is possible that these differences reflect a neuralabneural gradient of response to Notch inhibition as well as an apical-basal response. Alternatively, since different supporting cell types express different combinations of Hes and Hey genes (Zheng et al., 2000; Zine et al., 2001; Hayashi et al., 2008; Li et al., 2008; Doetzlhofer et al., 2009; Murata et al., 2009; Tateya et al., 2011), it is possible that these differences reflect the different sensitivities of these Notch target genes to Notch inhibition (Ong et al., 2006).

We observe a down-regulation of mRNA levels of Notch receptors, ligands and downstream effectors in the first postnatal week. The degree and rate of down-regulation varies, but analysis of Notch1 signaling in cochlear supporting cells over this time 
period (Figure 5; Murata et al., 2006; Basch et al., 2011) suggests that very little cleavage of the Notch1 receptor is occurring by the end of the first postnatal week. The mechanism of this downregulation is currently not known, although given the absence of significant Notch pathway expression in the adult cochlea, it is possible that the loci of Notch pathway genes are becoming epigenetically modified and placed beyond use. It is also possible that this epigenetic silencing is accompanied by silencing of the direct targets of Notch effectors such as the Hes and Hey genes. However, it should be noted that the Notch pathway appears to be down-regulated in mature supporting cells in the chicken basilar papilla, as this sensory organ also fails to respond to gamma secretase inhibitors in the undamaged state (Daudet et al., 2009). Nevertheless, after damage, the Notch pathway is once again deployed in chicken supporting cells and the differentiating hair cells that they generate (Stone and Rubel, 1999; Daudet et al., 2009). It will therefore be of great interest to identify the epigenetic state of Notch pathway genes and their targets in mature mammalian supporting cells. It should also be noted that the co-expression of Jag1 and Sox2, which is seen in sensory patches from their first appearance (Kiernan et al., 2005b; Pan et al., 2010, 2013; Neves et al., 2011, 2012), is maintained in adult mouse supporting cells (Oesterle et al., 2008). It is thus formally possible that low levels of Notch signaling may persist in the adult cochlea and may maintain expression of these two genes by lateral induction. If this is the case, such signaling does not appear to confer competence for regeneration on supporting cells.

A recent study demonstrated that a small but significant number of new hair cells could be generated from supporting cells by treating noise-damaged animals with gamma secretase inhibitors (Mizutari et al., 2013), leading to a partial restoration of function. How can we reconcile these results with our data in the present study? First, it is possible that the Notch pathway can continue to regulate hair cell and supporting cell fate in the adult animal when expressed at significantly lower levels. We feel this is unlikely since binding of the Notch-ICD-MAML$\mathrm{RBPj}$ complex to its target sites in the genome is likely to be severely compromised at low concentrations of Notch-ICD (Ong et al., 2006). Second, it is possible that a sub-population of supporting cells continue to express Notch pathway components at significant levels, but that these would not be detected when analyzing gene expression in the entire cochlea. In our single cell analysis of 123 P21 pillar cells and Deiters' cells, we were

\section{References}

Abelló, G., Khatri, S., Giráldez, F., and Alsina, B. (2007). Early regionalization of the otic placode and its regulation by the Notch signaling pathway. Mech. Dev. 124, 631-645. doi: 10.1016/j.mod.2007.04.002

Adam, J., Myat, A., Le Roux, I., Eddison, M., Henrique, D., Ish-Horowicz, D., et al. (1998). Cell fate choices and the expression of Notch, Delta and Serrate homologues in the chick inner ear: parallels with Drosophila sense-organ development. Development 125, 4645-4654.

Artavanis-Tsakonas, S., and Muskavitch, M. A. (2010). Notch: the past, the present and the future. Curr. Top. Dev. Biol. 92, 1-29. doi: 10.1016/s00702153(10)92001-2 able to detect a very small number of cells in which Notch pathway components were expressed at comparable levels to their neonatal counterparts (Figure 6), and levels of Hes5 and the hair cell marker Atoh1 are more than 10-fold lower in the adult, even after noise damage (Figure 7). This suggests that if such cells persist in the adult cochlea, they are present in extremely small numbers. Finally, it is also possible that a second, Notch-independent pathway that can be targeted by gamma secretase inhibitors is operating in a small number of mature supporting cells. The effect of inhibiting this second pathway would be overshadowed by Notch inhibition in the neonatal cochlea, but might be uncovered in the adult cochlea when the Notch pathway is no longer active. It should also be noted that the noise damage protocol (Liu et al., 2011) used in our study-98 dB for $4 \mathrm{~h}$-is significantly less severe than the protocol used by Mizutari et al. (116 dB for $2 \mathrm{~h}$ ). However, the large and significant drop in Atoh1 and Hes5 levels we observe in undamaged adult tissue compared to neonatal animals still supports our observed down-regulation of Notch pathway genes in the first postnatal week.

In conclusion, our results suggest that the canonical Notch pathway is not active to any significant degree in the adult organ of Corti, and that the down-regulation of signaling occurs prior to the onset of hearing. The Notch pathway can therefore be viewed as a developmental scaffold for the organ of Corti-it is partly necessary for establishing the pattern and proportion of hair cells and supporting cells, but not necessary to maintain this pattern once it has been established. This suggests that inhibition of Notch signaling in the adult organ of Corti in the absence of other manipulations is unlikely to promote significant numbers of new hair cells, and that alternative or supplementary therapeutic interventions should be considered.

\section{Acknowledgments}

We thank Alyssa Crowder, Hongyuan Zhang and Huiling Li for excellent technical support. We thank Gerry Weinmaster, Urban Lendahl, Ryoichiro Kageyama and Manfred Gessler for gifts of cDNA probes. This work was supported by Department of Defense Grant DOD W81XWH-11-2-004 (AKG) and Hearing Restoration Project consortium grants from the Hearing Health Foundation (AKG and SH), NIH grant DC004563 (SH), NIH grant P30 DC010363 (SH, JSO), and NIH R01 DC014450 (JSO).
Artavanis-Tsakonas, S., Rand, M. D., and Lake, R. J. (1999). Notch signaling: cell fate control and signal integration in development. Science 284, 770-776. doi: 10.1126/science.284.5415.770

Basch, M. L., Ohyama, T., Segil, N., and Groves, A. K. (2011). Canonical Notch signaling is not necessary for prosensory induction in the mouse cochlea: insights from a conditional mutant of RBPjkappa. J. Neurosci. 31, 8046-8058. doi: 10.1523/jneurosci.6671-10.2011

Batts, S. A., Shoemaker, C. R., and Raphael, Y. (2009). Notch signaling and Hes labeling in the normal and drug-damaged organ of corti. Hear. Res. 249, 15-22. doi: 10.1016/j.heares.2008.12.008

Benito-Gonzalez, A., and Doetzlhofer, A. (2014). Heyl and hey2 control the spatial and temporal pattern of mammalian auditory hair cell differentiation 
downstream of hedgehog signaling. J. Neurosci. 34, 12865-12876. doi: 10. 1523/jneurosci.1494-14.2014

Birren, S. J., Lo, L., and Anderson, D. J. (1993). Sympathetic neuroblasts undergo a developmental switch in trophic dependence. Development 119, 597-610.

Bramhall, N. F., Shi, F., Arnold, K., Hochedlinger, K., and Edge, A. S. (2014). Lgr5positive supporting cells generate new hair cells in the postnatal cochlea. Stem Cell Reports 2, 311-322. doi: 10.1016/j.stemcr.2014.01.008

Bray, S. J. (2006). Notch signalling: a simple pathway becomes complex. Nat. Rev. Mol. Cell Biol. 7, 678-689. doi: 10.1038/nrm2009

Brooker, R., Hozumi, K., and Lewis, J. (2006). Notch ligands with contrasting functions: Jagged1 and Deltal in the mouse inner ear. Development 133, 1277-1286. doi: $10.1242 /$ dev.02284

Cai, T., Seymour, M. L., Zhang, H., Pereira, F. A., and Groves, A. K. (2013). Conditional deletion of Atoh1 reveals distinct critical periods for survival and function of hair cells in the organ of corti. J. Neurosci. 33, 10110-10122. doi: 10. 1523/JNEUROSCI.5606-12.2013

Chen, P., Johnson, J. E., Zoghbi, H. Y., and Segil, N. (2002). The role of Math1 in inner ear development: uncoupling the establishment of the sensory primordium from hair cell fate determination. Development 129, 2495-2505.

Chitnis, A. B. (1995). The role of Notch in lateral inhibition and cell fate specification. Mol. Cell. Neurosci. 6, 311-321. doi: 10.1006/mcne.1995.1024

Cox, B. C., Liu, Z., Lagarde, M. M., and Zuo, J. (2012). Conditional gene expression in the mouse inner ear using Cre-loxP. J. Assoc. Res. Otolaryngol. 13, 295-322. doi: 10.1007/s10162-012-0324-5

Daudet, N., Ariza-Mcnaughton, L., and Lewis, J. (2007). Notch signalling is needed to maintain, but not to initiate, the formation of prosensory patches in the chick inner ear. Development 134, 2369-2378. doi: 10.1242/dev.001842

Daudet, N., Gibson, R., Shang, J., Bernard, A., Lewis, J., and Stone, J. (2009). Notch regulation of progenitor cell behavior in quiescent and regenerating auditory epithelium of mature birds. Dev. Biol. 326, 86-100. doi: 10.1016/j.ydbio.2008. 10.033

Daudet, N., and Lewis, J. (2005). Two contrasting roles for Notch activity in chick inner ear development: specification of prosensory patches and lateral inhibition of hair-cell differentiation. Development 132, 541-551. doi: 10. 1242/dev.01589

Doetzlhofer, A., Basch, M. L., Ohyama, T., Gessler, M., Groves, A. K., and Segil, N. (2009). Hey2 regulation by FGF provides a Notch-independent mechanism for maintaining pillar cell fate in the organ of corti. Dev. Cell 16, 58-69. doi: 10. 1016/j.devcel.2008.11.008

Durruthy-Durruthy, R., Gottlieb, A., Hartman, B. H., Waldhaus, J., Laske, R. D., Altman, R., et al. (2014). Reconstruction of the mouse otocyst and early neuroblast lineage at single-cell resolution. Cell 157, 964-978. doi: 10.1016/j. cell.2014.03.036

Eagleson, K. L., Schlueter Mcfadyen-Ketchum, L. J., Ahrens, E. T., Mills, P. H., Does, M. D., Nickols, J., et al. (2007). Disruption of Foxg1 expression by knockin of cre recombinase: effects on the development of the mouse telencephalon. Neuroscience 148, 385-399. doi: 10.1016/j.neuroscience.2007.06.012

Eddison, M., Le Roux, I., and Lewis, J. (2000). Notch signaling in the development of the inner ear: lessons from Drosophila. Proc. Natl. Acad. Sci. U S A 97, 11692-11699. doi: 10.1073/pnas.97.22.11692

Formosa-Jordan, P., Ibañes, M., Ares, S., and Frade, J. M. (2013). Lateral inhibition and neurogenesis: novel aspects in motion. Int. J. Dev. Biol. 57, 341-350. doi: 10. 1387/ijdb.120259jf

Groves, A. K., and Fekete, D. M. (2012). Shaping sound in space: the regulation of inner ear patterning. Development 139, 245-257. doi: 10.1242/dev.067074

Groves, A. K., George, K. M., Tissier-Seta, J. P., Engel, J. D., Brunet, J. F., and Anderson, D. J. (1995). Differential regulation of transcription factor gene expression and phenotypic markers in developing sympathetic neurons. Development 121, 887-901.

Harland, R. M. (1991). In situ hybridization: an improved whole-mount method for Xenopus embryos. Methods Cell Biol. 36, 685-695. doi: 10.1016/s0091679x(08)60307-6

Hartman, B. H., Basak, O., Nelson, B. R., Taylor, V., Bermingham-Mcdonogh, O., and Reh, T. A. (2009). Hes5 expression in the postnatal and adult mouse inner ear and the drug-damaged cochlea. J. Assoc. Res. Otolaryngol. 10, 321-340. doi: 10.1007/s10162-009-0162-2

Hartman, B. H., Hayashi, T., Nelson, B. R., Bermingham-Mcdonogh, O., and Reh, T. A. (2007). Dll3 is expressed in developing hair cells in the mammalian cochlea. Dev. Dyn. 236, 2875-2883. doi: 10.1002/dvdy.21307
Hartman, B. H., Reh, T. A., and Bermingham-Mcdonogh, O. (2010). Notch signaling specifies prosensory domains via lateral induction in the developing mammalian inner ear. Proc. Natl. Acad. Sci. U S A 107, 15792-15797. doi: 10. 1073/pnas. 1002827107

Hayashi, T., Kokubo, H., Hartman, B. H., Ray, C. A., Reh, T. A., and BerminghamMcdonogh, O. (2008). Hesr1 and Hesr2 may act as early effectors of Notch signaling in the developing cochlea. Dev. Biol. 316, 87-99. doi: 10.1016/j.ydbio. 2008.01.006

Hori, R., Nakagawa, T., Sakamoto, T., Matsuoka, Y., Takebayashi, S., and Ito, J. (2007). Pharmacological inhibition of Notch signaling in the mature guinea pig cochlea. Neuroreport 18, 1911-1914. doi: 10.1097/wnr.0b013e3282f213e0

Hori, K., Sen, A., and Artavanis-Tsakonas, S. (2013). Notch signaling at a glance. J. Cell Sci. 126, 2135-2140. doi: 10.1242/jcs. 127308

Ilagan, M. X., and Kopan, R. (2007). SnapShot: notch signaling pathway. Cell 128, 1246.e1-1246.e2. doi: 10.1016/j.cell.2007.03.011

Jayasena, C. S., Ohyama, T., Segil, N., and Groves, A. K. (2008). Notch signaling augments the canonical Wnt pathway to specify the size of the otic placode. Development 135, 2251-2261. doi: 10.1242/dev.017905

Kelley, M. W. (2003). Cell adhesion molecules during inner ear and hair cell development, including notch and its ligands. Curr. Top. Dev. Biol. 57, 321-356. doi: 10.1016/s0070-2153(03)57011-9

Kelley, M. W. (2006). Regulation of cell fate in the sensory epithelia of the inner ear. Nat. Rev. Neurosci. 7, 837-849. doi: 10.1038/nrn1987

Kelley, M. W. (2007). Cellular commitment and differentiation in the organ of corti. Int. J. Dev. Biol. 51, 571-583. doi: 10.1387/ijdb.072388mk

Khatri, S. B., and Groves, A. K. (2013). Expression of the Foxi2 and Foxi3 transcription factors during development of chicken sensory placodes and pharyngeal arches. Gene Expr. Patterns 13, 38-42. doi: 10.1016/j.gep.2012. 10.001

Kiernan, A. E. (2013). Notch signaling during cell fate determination in the inner ear. Semin. Cell Dev. Biol. 24, 470-479. doi: 10.1016/j.semcdb.2013.04.002

Kiernan, A. E., Cordes, R., Kopan, R., Gossler, A., and Gridley, T. (2005a). The Notch ligands DLL1 and JAG2 act synergistically to regulate hair cell development in the mammalian inner ear. Development 132, 4353-4362. doi: $10.1242 / \mathrm{dev} .02002$

Kiernan, A. E., Pelling, A. L., Leung, K. K., Tang, A. S., Bell, D. M., Tease, C., et al. (2005b). Sox 2 is required for sensory organ development in the mammalian inner ear. Nature 434, 1031-1035. doi: 10.1038/nature03487

Kopan, R., and Ilagan, M. X. (2004). Gamma-secretase: proteasome of the membrane? Nat. Rev. Mol. Cell Biol. 5, 499-504. doi: 10.1038/nrm1406

Korrapati, S., Roux, I., Glowatzki, E., and Doetzlhofer, A. (2013). Notch signaling limits supporting cell plasticity in the hair cell-damaged early postnatal murine cochlea. PLoS One 8:e73276. doi: 10.1371/journal.pone.0073276

Lewis, J. (1991). Rules for the production of sensory cells. Ciba Found. Symp. 160, 25-39; discussion 40-53.

Li, H., Collado, M., Villasante, A., Matheu, A., Lynch, C. J., Cañamero, M., et al. (2012). p27(Kip1) directly represses Sox2 during embryonic stem cell differentiation. Cell Stem Cell 11, 845-852. doi: 10.1016/j.stem.2012.09.014

Li, S., Mark, S., Radde-Gallwitz, K., Schlisner, R., Chin, M. T., and Chen, P. (2008). Hey 2 functions in parallel with Hes 1 and Hes 5 for mammalian auditory sensory organ development. BMC Dev. Biol. 8:20. doi: 10.1186/1471-213X-8-20

Li, W., Wu, J., Yang, J., Sun, S., Chai, R., Chen, Z. Y., et al. (2015). Notch inhibition induces mitotically generated hair cells in mammalian cochleae via activating the Wnt pathway. Proc. Natl. Acad. Sci. U S A 112, 166-171. doi: 10.1073/pnas. 1415901112

Lin, V., Golub, J. S., Nguyen, T. B., Hume, C. R., Oesterle, E. C., and Stone, J. S. (2011). Inhibition of Notch activity promotes nonmitotic regeneration of hair cells in the adult mouse utricles. J. Neurosci. 31, 15329-15339. doi: 10 1523/JNEUROSCI.2057-11.2011

Liu, C. C., Gao, S. S., Yuan, T., Steele, C., Puria, S., and Oghalai, J. S. (2011). Biophysical mechanisms underlying outer hair cell loss associated with a shortened tectorial membrane. J. Assoc. Res. Otolaryngol. 12, 577-594. doi: 10. 1007/s10162-011-0269-0

Liu, Z., Liu, Z., Walters, B. J., Owen, T., Kopan, R., and Zuo, J. (2013). In vivo visualization of Notch1 proteolysis reveals the heterogeneity of Notch1 signaling activity in the mouse cochlea. PLoS One 8:e64903. doi: 10. 1371/journal.pone.0064903

Liu, Z., Owen, T., Fang, J., Srinivasan, R. S., and Zuo, J. (2012a). In vivo Notch reactivation in differentiating cochlear hair cells induces Sox2 and Prox1 
expression but does not disrupt hair cell maturation. Dev. Dyn. 241, 684-696. doi: $10.1002 /$ dvdy.23754

Liu, Z., Owen, T., Fang, J., and Zuo, J. (2012b). Overactivation of Notch1 signaling induces ectopic hair cells in the mouse inner ear in an age-dependent manner. PLoS One 7:e34123. doi: 10.1371/journal.pone.0034123

Lumpkin, E. A., Collisson, T., Parab, P., Omer-Abdalla, A., Haeberle, H., Chen, P., et al. (2003). Math1-driven GFP expression in the developing nervous system of transgenic mice. Gene Expr. Patterns 3, 389-395. doi: 10.1016/s1567$133 \mathrm{x}(03) 00089-9$

Mizutari, K., Fujioka, M., Hosoya, M., Bramhall, N., Okano, H. J., Okano, H., et al. (2013). Notch inhibition induces cochlear hair cell regeneration and recovery of hearing after acoustic trauma. Neuron 77, 58-69. doi: 10.1016/j.neuron.2012. 10.032

Morimoto, M., Liu, Z., Cheng, H. T., Winters, N., Bader, D., and Kopan, R. (2010). Canonical Notch signaling in the developing lung is required for determination of arterial smooth muscle cells and selection of Clara versus ciliated cell fate. J. Cell Sci. 123, 213-224. doi: 10.1242/jcs.058669

Murata, J., Ikeda, K., and Okano, H. (2012). Notch signaling and the developing inner ear. Adv. Exp. Med. Biol. 727, 161-173. doi: 10.1007/978-1-46140899-4_12

Murata, J., Ohtsuka, T., Tokunaga, A., Nishiike, S., Inohara, H., Okano, H., et al. (2009). Notch-Hes1 pathway contributes to the cochlear prosensory formation potentially through the transcriptional down-regulation of p27Kip1. J. Neurosci. Res. 87, 3521-3534. doi: 10.1002/jnr.22169

Murata, J., Tokunaga, A., Okano, H., and Kubo, T. (2006). Mapping of notch activation during cochlear development in mice: implications for determination of prosensory domain and cell fate diversification. J. Comp. Neurol. 497, 502-518. doi: 10.1002/cne.20997

Neves, J., Abelló, G., Petrovic, J., and Giraldez, F. (2013a). Patterning and cell fate in the inner ear: a case for Notch in the chicken embryo. Dev. Growth Differ. 55, 96-112. doi: 10.1111/dgd.12016

Neves, J., Parada, C., Chamizo, M., and Giráldez, F. (2011). Jagged 1 regulates the restriction of Sox2 expression in the developing chicken inner ear: a mechanism for sensory organ specification. Development 138, 735-744. doi: 10.1242/dev. 060657

Neves, J., Uchikawa, M., Bigas, A., and Giraldez, F. (2012). The prosensory function of Sox 2 in the chicken inner ear relies on the direct regulation of Atoh1. PLoS One 7:e30871. doi: 10.1371/journal.pone.0030871

Neves, J., Vachkov, I., and Giraldez, F. (2013b). Sox2 regulation of hair cell development: incoherence makes sense. Hear. Res. 297, 20-29. doi: 10.1016/j. heares.2012.11.003

Oesterle, E. C., Campbell, S., Taylor, R. R., Forge, A., and Hume, C. R. (2008). Sox2 and JAGGED1 expression in normal and drug-damaged adult mouse inner ear. J. Assoc. Res. Otolaryngol. 9, 65-89. doi: 10.1007/s10162-007-0106-7

Ong, C. T., Cheng, H. T., Chang, L. W., Ohtsuka, T., Kageyama, R., Stormo, G. D., et al. (2006). Target selectivity of vertebrate notch proteins. Collaboration between discrete domains and CSL-binding site architecture determines activation probability. J. Biol. Chem. 281, 5106-5119. doi: 10.1074/jbc. m506108200

Pan, W., Jin, Y., Chen, J., Rottier, R. J., Steel, K. P., and Kiernan, A. E. (2013). Ectopic expression of activated notch or SOX2 reveals similar and unique roles in the development of the sensory cell progenitors in the mammalian inner ear. J. Neurosci. 33, 16146-16157. doi: 10.1523/JNEUROSCI.3150-12.2013

Pan, W., Jin, Y., Stanger, B., and Kiernan, A. E. (2010). Notch signaling is required for the generation of hair cells and supporting cells in the mammalian inner ear. Proc. Natl. Acad. Sci. U S A 107, 15798-15803. doi: 10.1073/pnas.1003089107

Rose, M. F., Ren, J., Ahmad, K. A., Chao, H. T., Klisch, T. J., Flora, A., et al. (2009). Math1 is essential for the development of hindbrain neurons critical for perinatal breathing. Neuron 64, 341-354. doi: 10.1016/j.neuron.2009.10.023

Shen, L., Nam, H. S., Song, P., Moore, H., and Anderson, S. A. (2006). FoxG1 haploinsufficiency results in impaired neurogenesis in the postnatal hippocampus and contextual memory deficits. Hippocampus 16, 875-890. doi: 10.1002/hipo.20218

Siegenthaler, J. A., Tremper-Wells, B. A., and Miller, M. W. (2008). Foxg1 haploinsufficiency reduces the population of cortical intermediate progenitor cells: effect of increased p21 expression. Cereb. Cortex 18, 1865-1875. doi: 10. 1093/cercor/bhm209

Slowik, A. D., and Bermingham-McDonogh, O. (2013). Hair cell generation by notch inhibition in the adult mammalian cristae. J. Assoc. Res. Otolaryngol. 14, 813-828. doi: 10.1007/s10162-013-0414-z

Stern, C. D. (1998). Detection of multiple gene products simultaneously by in situ hybridization and immunohistochemistry in whole mounts of avian embryos. Curr. Top. Dev. Biol. 36, 223-243. doi: 10.1016/s0070-2153(08) 60505-0

Stone, J. S., and Cotanche, D. A. (2007). Hair cell regeneration in the avian auditory epithelium. Int. J. Dev. Biol. 51, 633-647. doi: 10.1387/ijdb.072408js

Stone, J. S., and Rubel, E. W. (1999). Delta1 expression during avian hair cell regeneration. Development 126, 961-973.

Takebayashi, S., Yamamoto, N., Yabe, D., Fukuda, H., Kojima, K., Ito, J., et al. (2007). Multiple roles of Notch signaling in cochlear development. Dev. Biol. 307, 165-178. doi: 10.1016/j.ydbio.2007.04.035

Tateya, T., Imayoshi, I., Tateya, I., Ito, J., and Kageyama, R. (2011). Cooperative functions of Hes/Hey genes in auditory hair cell and supporting cell development. Dev. Biol. 352, 329-340. doi: 10.1016/j.ydbio.2011.01.038

Tona, Y., Hamaguchi, K., Ishikawa, M., Miyoshi, T., Yamamoto, N., Yamahara, K., et al. (2014). Therapeutic potential of a gamma-secretase inhibitor for hearing restoration in a guinea pig model with noise-induced hearing loss. BMC Neurosci. 15:66. doi: 10.1186/1471-2202-15-66

Wang, G. P., Chatterjee, I., Batts, S. A., Wong, H. T., Gong, T. W., Gong, S. S., et al. (2010). Notch signaling and Atoh1 expression during hair cell regeneration in the mouse utricle. Hear. Res. 267, 61-70. doi: 10.1016/j.heares.2010. 03.085

Wu, Y., Cain-Hom, C., Choy, L., Hagenbeek, T. J., de Leon, G. P., Chen, Y., et al. (2010). Therapeutic antibody targeting of individual Notch receptors. Nature 464, 1052-1057. doi: 10.1038/nature08878

Xia, A., Song, Y., Wang, R., Gao, S. S., Clifton, W., Raphael, P., et al. (2013). Prestin regulation and function in residual outer hair cells after noise-induced hearing loss. PLoS One 8:e82602. doi: 10.1371/journal.pone.0082602

Yamamoto, N., Chang, W., and Kelley, M. W. (2011). Rbpj regulates development of prosensory cells in the mammalian inner ear. Dev. Biol. 353, 367-379. doi: 10 1016/j.ydbio.2011.03.016

Yamamoto, N., Tanigaki, K., Tsuji, M., Yabe, D., Ito, J., and Honjo, T. (2006) Inhibition of Notch/RBP-J signaling induces hair cell formation in neonate mouse cochleas. J. Mol. Med. (Berl) 84, 37-45. doi: 10.1007/s00109-0050706-9

Young, K. M., Mitsumori, T., Pringle, N., Grist, M., Kessaris, N., and Richardson, W. D. (2010). An Fgfr3-iCreER(T2) transgenic mouse line for studies of neural stem cells and astrocytes. Glia 58, 943-953. doi: 10.1002/glia. 20976

Zheng, J. L., Shou, J., Guillemot, F., Kageyama, R., and Gao, W. Q. (2000). Hes1 is a negative regulator of inner ear hair cell differentiation. Development 127 , 4551-4560.

Zine, A., Aubert, A., Qiu, J., Therianos, S., Guillemot, F., Kageyama, R., et al. (2001). Hes 1 and Hes5 activities are required for the normal development of the hair cells in the mammalian inner ear. J. Neurosci. 21, 4712-4720.

Zine, A., Van De Water, T. R., and de Ribaupierre, F. (2000). Notch signaling regulates the pattern of auditory hair cell differentiation in mammals. Development $127,3373-3383$.

Conflict of Interest Statement: The authors declare that the research was conducted in the absence of any commercial or financial relationships that could be construed as a potential conflict of interest.

Copyright (c) 2015 Maass, Gu, Basch, Waldhaus, Lopez, Xia, Oghalai, Heller and Groves. This is an open-access article distributed under the terms of the Creative Commons Attribution License (CC BY). The use, distribution and reproduction in other forums is permitted, provided the original author(s) or licensor are credited and that the original publication in this journal is cited, in accordance with accepted academic practice. No use, distribution or reproduction is permitted which does not comply with these terms. 